\title{
Assessing the Water Quality Response to an Alternative Sewage Disposal Strategy at Bathing Sites on the East Coast of Ireland
}

\author{
Zeinab Bedri \\ Technological University Dublin, zeinab.bedri@tudublin.ie \\ John O'Sullivan \\ University College Dublin, jj.osullivan@ucd.ie \\ Louise Deering \\ University College Dublin
}

See next page for additional authors

Follow this and additional works at: https://arrow.tudublin.ie/engschcivart

Part of the Civil Engineering Commons, and the Environmental Engineering Commons

\section{Recommended Citation}

Bedei, Z. et al. (2015) Assessing the Water Quality Response to an Alternative Sewage Disposal Strategy at Bathing Sites on the East Coast of Ireland, Marine Pollution Bulletin, Vol. 91, No. 1, pp 330-346.

https://doi.org/10.1016/j.marpolbul.2014.11.008

This Article is brought to you for free and open access by the School of Civil and Structural Engineering at ARROW@TU Dublin. It has been accepted for inclusion in Articles by an authorized administrator of ARROW@TU Dublin. For more information, please contact arrow.admin@tudublin.ie, aisling.coyne@tudublin.ie, gerard.connolly@tudublin.ie.

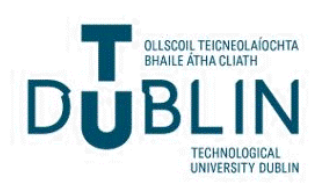




\section{Authors}

Zeinab Bedri, John O'Sullivan, Louise Deering, Katalin Demeter, Bartholomew Masterson, Wim Meijer, and Gregory O'Hare 
Dublin Institute of Technology

ARROW@DIT

$2015-2$

\section{Assessing the water quality response to an alternative sewage disposal strategy at bathing sites on the east coast of Ireland}

Zeinab Bedri

John O'Sullivan

Louise Deering

Katalin Demeter

Bartholomew Masterson

See next page for additional authors

Follow this and additional works at: https://arrow.dit.ie/engschcivart

Part of the Civil Engineering Commons, and the Environmental Engineering Commons

This Article is brought to you for free and open access by the School of Civil and Structural Engineering at ARROW@DIT. It has been accepted for inclusion in Articles by an authorized administrator of ARROW@DIT. For more information, please contact yvonne.desmond@dit.ie, arrow.admin@dit.ie, brian.widdis@dit.ie. 
Authors

Zeinab Bedri, John O'Sullivan, Louise Deering, Katalin Demeter, Bartholomew Masterson, Wim Meijer, and Gregory O'Hare 


\title{
Click here to view linked References
}

1

\section{Assessing the water quality response to an alternative sewage disposal strategy at bathing sites on the east coast of Ireland}

\author{
Zeinab Bedri ${ }^{\text {a*, John J. O'Sullivan }{ }^{\mathrm{a}} \text {, Louise A. Deering }}{ }^{\mathrm{b}}$, Katalin Demeter ${ }^{\mathrm{b}}$, Bartholomew \\ Masterson $^{b}$, Wim G.Meijer ${ }^{b}$ and Gregory O'Hare ${ }^{c}$
}

a Dooge Centre for Water Resources Research, School of Civil, Structural, and Environmental Engineering, University College Dublin, Belfield, Dublin 4, Ireland

b School of Biomolecular and Biomedical Science, University College Dublin, Belfield, Dublin 4, Ireland.

c Clarity Centre, UCD School of Computer Science and Informatics, University College Dublin, Belfield, Dublin 4, Ireland

* Corresponding author: Tel. +353 1716 3228, Fax: +353 1 7163297, E-mail: zeinab.bedri@ucd.ie

\begin{abstract}
A three-dimensional model is used to assess the bathing water quality of two beaches following changes to the sewage management system. The model, firstly was first calibrated to hydrodynamic and water quality data from the period prior to upgrade of sewage treatment works (STWs), was : tThen it was-used to simulate Escherichia coli distributions for discharge scenarios of the periods prior to and following the upgrade of the STWs under dry and wet weather conditions. Escherichia coli distributions under dry weather conditions demonstrate that the upgrade in the treatment worksSTWs has remarkably improved the bathing water qualityquality to a Blue Flag status. Consequently, the Blue Flag status at the two beaches would be regained.

The new discharge strategy is expected to drastically reduce the rainfall-related incidents in which environmental limits of the Bathing Water Directive are breached. However, significant exceedances to these limits may still occur under wet weather conditions at Bray beach due to storm overflows that may still be discharged through the two Bray outfalls.
\end{abstract}


Keywords: Sewage discharges; three-dimensional model; bathing water quality; Escherichia coli

\section{Introduction}

The discharge of raw or partially treated sewage into coastal waters is a worldwide practice that offers an economical solution to sewage disposal but often conflicts with marine recreational and aquaculture activities. Achieving and maintaining a balance between sewage disposal and the other uses of marine waters is becoming increasingly challenging due to the growing demands for good water quality in these environments, coupled with the need to meet the requirements of EU environmental legislations such as the Urban Wastewater Treatment Directive 91/271/EEC (EEC, 1991), Shellfish Water Directive 2006/113/EC (EC, 2006a) and the Bathing Water Directives 76/160/EEC (EEC, 1976) and 2006/7/EC (EC, 2006b).

Since the introduction of the first Bathing Water Directive 76/160/EEC (EEC, 1976), there has been substantial investments by EU member states to reduce the impact of sewage discharges on coastal waters in order to achieve compliance with the strict water quality standards of the directive (see for example Christoulas and Andreadakis, 1995; Hewett, 2007; Martín et al, 2007; García-Barcina et al. 2006; Chang et al., 2012). These standards will become more stringent due to the enforcement of the revised Bathing Water Directive in December 2014. Failure to comply with the standards of the revised Directive and the consequent closing of beaches will have serious economic implications to the tourism industry of a number of EU member states (see Hynes et al., 2013; Georgiou and Bateman, 2005). In Ireland, two bathing sites on the east coast; Bray and Killiney (Figure 1) are of national recreational and heritage importance. Until recently, a sewage disposal strategy had been in place where the coastal waters of Bray and Killiney beaches received continuous discharges from two main sources; namely the Bray Pumping Station (PS) and the Shanganagh wastewater Treatment Works (WwTW). Untreated sewage generated in the Bray catchment area was directly discharged into the marine waters through a long sea outfall, $1.6 \mathrm{~km}$ offshore of Bray beach and when the capacity of this was exceeded in wet weather events, a short sea outfall adjacent to Bray harbour (see Figure 1) was also used. In addition, the Shanganagh WwTW that serves the catchment area north of Bray, provided for primary treatment before discharging via a long sea outfall approximately $1.6 \mathrm{~km}$ off the shore of Killiney beach. A short sea outfall located approximately $1 \mathrm{~km}$ south of Killiney beach was also required at the Shanganagh WwTW during extreme weather events. The inadequate level of sewage treatment from the areas of Bray and Shanganagh and its uncontrolled discharge to the coastal waters off Bray and Killiney had contributed significantly to the decline of marine water quality in the area. To address this, a major upgrade to the sewage system serving Shanganagh and Bray was completed in October 2012. The upgrade facilitated the pumping of sewage from Bray to Shanganagh, thereby eliminating untreated sewage discharges from the Bray PS into the coastal 
waters for normal conditions, and allowed for an enhanced secondary level of treatment to be provided at the Shanganagh WwTW while also expanding its capacity to cater for a population equivalent of 250,000 (covering both Shanganagh and Bray catchments). For this purpose, a pipeline and holding tank were constructed to convey the sewage from Bray to the Shanganagh WwTW for treatment. The new disposal system caters for wet weather conditions by making provisions for the use of the long and short sea outfalls at Bray as storm overflows should the conveyance capacity to Shanganagh WwTW be exceeded. In extreme wet weather events the short sea outfall of Shanganagh WwTW may also be used. The new disposal system, however, does not currently include tertiary treatment (in the form of Ultra Violet disinfection) although there are provisions for its inclusion in the future. These changes to the sewage management strategy and their effect on the water quality of the EU designated beaches of Bray and Killiney are investigated in this paper.

Such changes to discharge strategies are generally assessed through long-term water quality monitoring programmes (see for example Bustamante et al, 2012; Xu et al, 2011; Taylor, 2010). This was not possible in the current case study since the available water quality data record at Bray and Killiney beaches following the upgrade works was limited and consisted of discrete determined from discrete-samples taken in during the bathing water season from between May and to-September of 2013. Therefore, a numerical model was used for the purpose of assessing the effect of the changed sewage management strategy on the bathing water quality at Bray and Killiney beaches. This is in keeping with the increasing use of numerical models in environmental impact studies as tools for predicting the flow and water quality distributions of pollutant discharges into the marine environment and numerous depth-averaged models of marine water quality models have been reported in the literature for such purposes (see for example Pritchard et al, 2013; Kashefipour et al, 2002, 2006; Schnauder et al, 2007; Bougaerd et al, 2011). Depth averaged coastal models may be adequate for well-mixed marine environments, but where vertical mixing is limited due to stratified flow fields which dominate the vicinity of discharge outfalls, a three-dimensional (3D) model becomes essential for improving the representation of the coastal hydrodynamics as highlighted by Bedri et al. (2011). Furthermore, the use of more sophisticated three-dimensional models (3D) is essential for the adequate modelling of die-off/ decay of faecal indicator bacteria (the main water quality indicators of the Bathing Water Directive 2006/7/EC). Bacteria die-off is a critical parameter for predicting its concentration after discharge, and can be affected by a number of environmental factors such as water temperature, salinity and light penetration into the water column. However, while some isolated studies are available (see for example Chan et al, 2013; Bedri et al, 2013; Thupaki et al, 2010), the prevalence of 3D modelling assessments of marine waters that incorporate these factors for bacterial modelling is less common in the main body of relevant scientific literature. 
This paper demonstrates the use of the 3D numerical model (TELEMAC-3D) as a tool for bathing water quality assessment and management. The model includes a 3D bacterial modelling function, incorporated by Bedri et al. (2013), to account for the effects of water temperature, salinity, and solar radiation on the die-off of bacteria. The model was used to examine the effectiveness of the changed sewage management strategy, in improving the bathing water quality at Bray and Killiney beaches and evaluates the need for tertiary treatment in the form of UV disinfection. The 3D model studied the distribution of Escherichia coli (E. coli) in the near-shore waters of the two bathing sites under a combination of varying weather and tidal conditions.

The paper is divided into five sections. Section 2 describes the study area and the changes to its sewage management system and following this, Section 3 outlines the TELEMAC-3D model used in the study. The model set-up and modelling scenarios are presented in Sections 4 and the findings of the study are discussed in Section 5. In Section 6, the conclusions drawn from the work are summarised.

\section{Study Area}

The coastal area under study is located on the east coast of Ireland (Longitude $6.1^{\circ} \mathrm{W}$, Latitude $53.22^{\circ} \mathrm{N}$ ). It is bounded to the north and the south by the Dalkey and Bray headlands respectively and extends for approximately $10 \mathrm{~km}$ in north-south direction. The topography of the seabed is such that it slopes gradually in the seawards direction (to the East) from low water to a depth of $8 \mathrm{~m}$ after which it falls more steeply to reach $20-25 \mathrm{~m}$ at a distance approximately $2 \mathrm{~km}$ offshore. Tidal streams in the outer coastal zone run north on a flood tide and south on an ebb tide and are roughly parallel to the coastline. Observations show that a flood tide enters the study region strongly from the south, but is deflected by Bray Head and runs parallel to the coastline before being deflected outwards by Dalkey Headland. The southwards flowing ebb tide also runs parallel to the coastline and serves to draw water out of Bray harbour. Tidal ranges in this region have a mean range of $2.75 \mathrm{~m}$ and average mean spring and neap tides of $3.6 \mathrm{~m}$ and $1.9 \mathrm{~m}$ respectively (Mansfield, 1992).

\section{Figure 1 here}

The Dargle River forms the main freshwater inflow into the coastal waters under study. The river, draining a catchment of circa $133 \mathrm{~km}^{2}$ (Bruen et al, 2001), enters the coastal area at Bray harbour (Figure 1). The Dargle River is characterised a by steep gradient of approximately $2.7 \%$ and has an average dry weather discharge of $3 \mathrm{~m}^{3} / \mathrm{s}$ which can rise significantly during storm events. However, a previous study quantifying the pollutant loads into the near-shore waters of Bray concluded that the wet weather contribution of the Dargle River is insignificant compared to the wet weather discharges 
of the Bray PS (Bruen, et al., 2001). Therefore the riverine contribution to the pollutant load into the coastal waters is ignored in the current work.

Prior to the upgrade works, the coastal waters under study received sewage discharges from both Bray PS and Shanganagh WwTW. The Bray PS, situated close to Bray harbour (Figure 1) received combined discharges from the town of Bray and some contiguous areas in Co. Wicklow (Population Equivalent of circa 37,000 in 2000). Following a pre-treatment screening routine in which grits and other materials were removed, the sewage was pumped through a $1.6 \mathrm{~km}$ pipe into the sea. A short sea outfall, adjacent to the north pier of Bray harbour provided an additional outlet that was sometimes required during extreme wet weather conditions. The Shanganagh WwTW serving a population equivalent of circa 66,000 in 2000 provided for primary treatment before discharging via a long sea outfall approximately $1.6 \mathrm{~km}$ offshore at Killiney beach (Figure 1). A capital investment of $€ 98.5 \mathrm{~m}$ was made in 2012 to: (i) convey wastewater from Bray PS to Shanganagh WwTW for treatment; (ii) construct a stormwater holding tank at Bray with a capacity of $5000 \mathrm{~m}^{3}$ to hold excess wastewater during wet weather events when the conveyance capacity from Bray to Shanganagh is exceeded (Roadbridge, 2014); and (iii) upgrade the level of treatment provided at the Shanganagh WwTW to full secondary treatment for up to $43,700 \mathrm{~m}^{3} / \mathrm{d}$ (SISK, 2014). Flows that are in excess of $43,700 \mathrm{~m}^{3} / \mathrm{d}$ may receive partial treatment. The upgrade works at the Shanganagh WwTW were completed in October 2012 to cater for a population equivalent of 250,000 , thereby having a degree of redundancy for future needs of both the Bray and Shanganagh catchments. Tertiary treatment (UV disinfection) is not currently included in the upgraded sewage treatment works but provision has been made for this to be included at a later date.

Wet weather events that result in discharges that exceed the capacity of the stormwater holding tank, are catered for by releasing excess discharges through the Bray long sea outfall, and if necessary, through the Bray short sea outfall. Discharges through the short sea outfall at Shanganagh WwTW take place only in extreme wet weather events.

However, no specific discharge threshold was targeted in the current study. The work presents a scenario-based comparison of the discharge conditions resulting from similar wet weather events that correspond to the periods prior to and following the upgrade of the Shanganagh WwTW. The wet weather scenarios in the current study are based on two rainfall events of low and high rainfall totals that correspond to the $25^{\text {th }}$ and $75^{\text {th }}$ percentiles respectively.

\section{Numerical Model}

TELEMAC-3D is a finite element model developed by the National Laboratory of Hydraulics and Environment of Electricité de France (EDF). It solves the three-dimensional Reynolds-Averaged Navier-Stokes (RANS) equations for free-surface flows (rivers, estuaries, seas, coastal waters, etc.) and incorporates the effect of temperature and salinity on water density, which in turn affects the flow 
dynamics (Hervouet, 2007). TELEMAC-3D is used in the current study to simulate the transport (advection and dispersion) and die-off of E. coli using the time- and space-dependant formula by Mancini (1978).

The current study applies the hydrostatic version of TELEMAC-3D which reduces the continuity and momentum equations to:

$\frac{\partial u}{\partial x}+\frac{\partial v}{\partial y}+\frac{\partial w}{\partial z}=0$

$\frac{\partial u}{\partial t}+u \frac{\partial u}{\partial x}+v \frac{\partial u}{\partial y}+w \frac{\partial u}{\partial z}$

$=-\frac{1}{\rho_{o}} \frac{\partial p}{\partial x}+\frac{\partial}{\partial x}\left(v_{H} \frac{\partial u}{\partial x}\right)+\frac{\partial}{\partial y}\left(v_{H} \frac{\partial u}{\partial y}\right)+\frac{\partial}{\partial z}\left(v_{Z} \frac{\partial u}{\partial z}\right)+S_{x}$

$\frac{\partial v}{\partial t}+u \frac{\partial v}{\partial x}+v \frac{\partial v}{\partial y}+w \frac{\partial v}{\partial z}$

$=-\frac{1}{\rho_{o}} \frac{\partial p}{\partial y}+\frac{\partial}{\partial x}\left(v_{H} \frac{\partial v}{\partial x}\right)+\frac{\partial}{\partial y}\left(v_{H} \frac{\partial v}{\partial y}\right)+\frac{\partial}{\partial z}\left(v_{Z} \frac{\partial v}{\partial z}\right)+S_{y}$

$p=p_{a t m}+\rho_{o} g(Z-z)+\rho_{o} g \int_{z}^{Z} \frac{\Delta \rho}{\rho_{o}} d z$

where $x, y$, and $z$ are the Cartesian axes, $u, v$, and $w$ are the velocity components in the $x, y$, and $z$ directions $\left(\mathrm{m} \mathrm{s}^{-1}\right), t$ is the time in seconds, $Z$ is the water surface elevation $(\mathrm{m}), p$ is the pressure $(\mathrm{N}$ $\left.\mathrm{m}^{-2}\right), \rho_{o}$ and $\Delta \rho$ are the reference density and variation in density respectively $\left(\mathrm{kg} \mathrm{m}^{-3}\right), S_{x}$ and $S_{y}$ are velocity source terms (wind, Coriolis force, etc.) $\left(\mathrm{m} \mathrm{s}^{-2}\right)$ and $v_{H}$ and $v_{Z}$ is the eddy viscosity in the horizontal and vertical direction respectively $\left(\mathrm{m}^{2} \mathrm{~s}^{-1}\right)$.

The mass-balance equation is used to calculate the time- and space-varying concentrations of temperature and salinity (both of which affect water density) and E. coli concentrations:

$$
\begin{aligned}
& \frac{\partial}{\partial t}(C)+u \frac{\partial}{\partial x}(C)+v \frac{\partial}{\partial y}(C)+w \frac{\partial}{\partial z}(C)=\frac{\partial}{\partial x}\left(K_{H} \frac{\partial}{\partial x}(C)\right) \\
& +\frac{\partial}{\partial y}\left(K_{H} \frac{\partial}{\partial y}(C)\right)+\frac{\partial}{\partial z}\left(K_{Z} \frac{\partial}{\partial z}(C)\right)+Q_{c}
\end{aligned}
$$

where $C$ is the concentration of tracer, $Q_{C}$ is the tracer source or sink term (e.g. decay of $E$. coli), and $K_{H}$ and $K_{Z}$ are the diffusivity coefficients in the horizontal and vertical directions respectively $\left(m^{2} s^{-1}\right)$. 
The values of temperature and salinity calculated for any point in space or time are used to compute the water density at that point using the state equation (Hervouet, 2007):

$$
\rho=\rho_{o}\left[1-\left[\left(T-T_{o}\right)^{2} \times 7-750 S\right] \times 10^{-6}\right]
$$

with $\rho_{o}=999.972 \mathrm{~kg} \mathrm{~m}^{-3}$ (reference density), $T_{o}=4{ }^{\circ} \mathrm{C}$ (reference temperature), and $S$ is the salinity measured in Practical Salinity Units $(P S U)$. The density variation in the flow field $(\Delta \rho / \rho$ in Equation 4) is hence calculated.

The decay of $E$. coli is modelled using the formula by Mancini (1978) which was incorporated in the mass-balance equation of TELEMAC-3D by Bedri et al. (2013). The formula produces a time- and space- varying die-off rate of $E$. coli:

$\frac{\partial C}{\partial t}=-k C$

$k=[0.8+0.006(\% s w)] * 1.07^{(T-20)}+\frac{I_{A}}{k_{e} H}\left[1-e^{-k_{e} H}\right]$

in which \%sw is the salinity expressed as a percentage of seawater (in the original form of equation by Mancini (1978)). In implementing the Mancini model, it was assumed that $100 \%$ sw corresponds to 35.5 PSU, one of the highest salinity values recorded by the authors in the study area; $I_{A}$ is the average daily surface solar radiation (langleys/hr) recorded at a nearby weather station (Dublin Airport); $H$ is the mixed water depth $(m)$; and $k_{e}$ is the light extinction coefficient $\left(m^{-1}\right)$. Due to the absence of information about the latter two variables for the study area, $k_{e} H$ was treated as a model parameter for the calibration of the $E$. coli model for which a range of values (0.15-1.0) was tested.

The decay rate of $E$. coli is generally expressed in terms of $T_{90}$ (the time taken for the $E$. coli concentration to be reduced by 90\%). The relationship between $k$ and $T_{90}$ is:

$k=\frac{2.303}{T_{90}}$

\subsection{Modelling Approach}


The TELEMAC-3D model was first set-up, calibrated and validated using hydrodynamic and water quality measurements corresponding to the period that precedes the upgrade works to the sewage disposal system. Following validation, the model was used to simulate the distribution of $E$. coli in the near-shore coastal waters under a number of discharge scenarios representing the periods prior to and following the upgrade works in order to assess and compare the bathing water quality at Bray and Killiney beaches under varying weather and tidal conditions.

\subsection{Data sources}

The available data for the set-up and calibration of the model consisted of an extensive bathymetric data set collated from Admiralty Charts in addition to previous bathymetric studies and surveys, together with a suite of hydrodynamic and water quality data (Table 1). The hydrodynamic data consisted of Acoustic Doppler Current Profiling (ADCP) and current-meter measurements that defined the vertical variations of current speed and direction in the water column for full mean neap and mid tidal cycles at nine sampling locations (denoted by Hydro in Figure 1). Tidal elevations at five reference gauges were also made available for the study. Moreover, depth profiles of temperature and salinity were taken at the mouth of Bray harbour (location A in Figure 1). The water quality data included E. coli samples at eleven offshore locations (locations WQ in Figure 1) taken during the period May - September, 2012. These were hourly samples taken at a depth of $0.5 \mathrm{~m}$ below the water surface throughout the duration of a tidal cycle (approximately 12 hours). The E. coli sampling covered the full range of tidal cycles (spring, mean and neap tides) in the Bray coastal zone. Once collected from the water surface, the water quality samples are stored in 11 bottles, and preserved in ice-packed containers until they have been analysed for E. coli. Microbial enumeration commenced within 24 hours of the sample being taken using the membrane filtration method (ISO, 2000).

To estimate the sewage loadings into the coastal zone, flow and water quality measurements at Bray PS and Shanganagh WwTW were obtained from the responsible Local Authority. The available data record consisted of flow and water quality measurements for an 18 months period ( $1^{\text {st }}$ January, 2012 to $30^{\text {th }}$ June 2013) spanning 9 months prior to the upgrade works ( $1^{\text {st }}$ January, 2012 to $30^{\text {th }}$ September, 2012) and 9 months (from $1^{\text {st }}$ October 2012 to $30^{\text {th }}$ June 2013) following the completion of the upgrade works. The data record comprised daily influent and effluent flow measurements, together with twice-weekly faecal coliform measurements of the effluent. Additional effluent samples from Shanganagh WwTW and the Bray Pumping Station were collected prior to the upgrade (as part of the current study) and analysed to obtain concentrations of E. coli in the effluent. For the estimation of the sewage loadings from Bray PS and Shanganagh WwTW used for the calibration stage of the model, daily discharges and E. coli concentrations of the effluent from the period prior to the upgrade works were used. The influent and effluent flow and water quality data record for the period from the 
$1^{\text {st }}$ January, 2012 to the $30^{\text {th }}$ June 2013 was used to generate the loadings for the simulated discharge scenarios.

\subsection{Model set-up and calibration}

Using the hydrodynamic and water quality data collected prior to the upgrade of the sewage treatment works, a two-stage process was completed for the set-up and calibration of the TELEMAC-3D model. The process initially involved calibrating the model for accurate prediction of the hydrodynamic characteristics in the model domain and following this, the water quality predicting component was calibrated to measured data.

\subsubsection{Hydrodynamics}

The coastal model domain extends for a distance of $64 \mathrm{~km}$ in the north-south direction and $44 \mathrm{~km}$ in the east-west direction. Extending the model domain far beyond the area of interest was necessary in order to minimise the effect of the model boundaries on the numerical solution. The domain was discretised using an extensive bathymetric data set (Table 1) to form a finite element mesh of 38,853 nodes and 73,122 elements that range in size from $25 \mathrm{~m}$ to $1.8 \mathrm{~km}$ (Figure 1). For the vertical discretisation of the model, five boundary fitting (sigma-transformed) layers were used. Preliminary simulations were conducted in which the number of vertical planes was varied from 5 to 9 . Comparisons of model outputs identified no significant loss of accuracy as a result of reducing the resolution of the vertical mesh to 5 layers and this resolution was used in the modelling process.

\section{Table 1 here}

The model has three open-sea boundaries; northern, eastern, and southern along which time- and space- varying water elevations (extracted from the Danish Hydraulic Institute (DHI) Global Tidal database (DHI, 2013)) were imposed. The DHI global model was based on the major diurnal and semi-diurnal tidal constituents (K1, O1, P1, Q1, M2, S2, N2, and K2), with a spatial resolution of $0.25^{\circ} \times 0.25^{\circ}$, which was validated against TOPEX/ POISEIDON altimetry data. To improve the propagation from the open-sea boundaries, amplitude and phase lags of the two largest constituents (M2 and S2) were adjusted sequentially in an exhaustive calibration routine. Tidal level predictions at five reference tidal gauges in the model domain (Figure 1) were compared to observations for a period of 33 days which exceeds a full lunar cycle of 29.5 days. A Fourier series analysis was performed on both the observed and simulated tidal levels to extract values of amplitudes and phase lags of the semi-diurnal tidal constituents (M2 and S2) at the five reference gauges.

The hydrodynamic component of the model was set-up using the mesh, initial conditions (background values of temperature and salinity, zero water velocities and a constant mean sea level) and boundary conditions (background values of temperature and salinity and the calibrated open-sea tidal elevations 
at the open sea boundaries). For the resolution of the horizontal turbulence, the Smagorinsky (1963) sub-grid scale model, with a length scale of 0.25 was chosen. The scheme is commonly used in maritime domains (see Marques et al. 2009; Sato et al. 2006; Hall and Davies, 2007) with large scale eddies where small vortices can be inhibited by the mesh. A Prandtl mixing length scale model with a Munk and Anderson (1948) damping function was used for the vertical turbulence closure. The hydrodynamics were calibrated by adjusting the bottom friction. The available measured time series of current velocity was split into two sets, with velocities at five locations being used for calibration and velocities at the rest of the locations being used for validation. Simulated depth profiles of temperature and salinity at the mouth of Bray harbour (location A) were also compared to measurements.

\subsubsection{Water quality}

After the calibration of the model hydrodynamics, the water quality component was set-up to simulate the transport and fate of E. coli in the coastal waters using: (i) E. coli flow and concentration data from Bray and Shanganagh sewage outfalls; (ii) initial/ background values of E. coli - these were set to zero but the model was initially run for a warm-up period of 6 tidal cycles to establish background conditions; and (iii) boundary conditions of E. coli - zero concentrations were imposed at the open-sea boundaries because previous dispersion and modelling studies in the Irish Sea (Crisp, 1976; Mansfield, 1992) suggest that the boundaries are located far out at sea where the distance from the shoreline is sufficient to negate the effect of boundary conditions on the computations in the area of interest (Bray and Killiney beaches). The $E$. coli model was calibrated by varying the $k_{e} H$ coefficient in the Mancini Formula (Equation 8) and comparing simulated E. coli to measurements at six of the water quality sampling locations (see Figure 1). The E. coli measurements at the remaining five sampling locations were used for model validation.

\section{3 Discharge scenarios}

Using the TELEMAC-3D model (calibrated to the hydrodynamics and water quality conditions that correspond to the period prior to the upgrade of the WwTW) a number of scenarios were formulated (Table 2) to simulate discharge conditions of the pre-upgrade period (denoted as Sc1 in Table 2) and those following the upgrade works (scenarios Sc2 in Table 2) in order to assess their impact on the bathing water quality of Bray and Killiney beaches. Three weather conditions were examined; dry (D), a wet weather event of low rainfall total (W1), and a wet weather of a higher rainfall total (W2). The simulations were based on two representative tide types; the mean spring tide (MST) and the mean neap tide (MNT). Loadings for the dry weather scenarios; MST-D-Sc1 and MNT-D-Sc1 (Table 2) corresponding to the pre-upgrade period ( $1^{\text {st }} \mathrm{Jan} 2012-30^{\text {th }}$ September 2012), were estimated 
using average dry weather effluent discharges and effluent water quality data at Bray PS and Shanganagh WwTW . Similarly, the average dry weather flow and effluent water quality data of the post-upgrade period ( $1^{\text {st }}$ October $2012-30^{\text {th }}$ June 2013) were used to compute the loadings for the post-upgrade dry weather scenarios MST-D-Sc2 and MNT-D-Sc2.

The formulation of the wet weather scenarios W1 and W2 involved a thorough analysis of the daily rainfall record of the catchment of the study area for the study period ( $1^{\text {st }}$ January 2012 to $30^{\text {th }}$ June 2013) to extract two sets of rainfall events of low and high rainfall totals corresponding to the pre- and post-upgrade periods. For the purpose of the analysis, the rainfall data along with influent flow data at Bray PS and Shanganagh WwTW for the period $1^{\text {st }}$ January $2012-30^{\text {th }}$ June, 2013, was split into two sets corresponding to the pre- and post-upgrade periods. These sets were then analysed and two events with rainfall totals of $25.0 \mathrm{~mm}$ and $22.8 \mathrm{~mm}$ were extracted from the pre and post-upgrade periods respectively to facilitate comparison for reasonably similar meteorological conditions. Rainfall totals of this magnitude approximated to the $25^{\text {th }}$ percentile of the data record $(23.0 \mathrm{~mm})$ and the total influent volumes generated at the treatment works for these events were similar. The loadings for these $25^{\text {th }}$ percentile rainfall scenarios (MST-W1-Sc1 and MST-W1-Sc2) were estimated based on effluent discharges and water quality measurements of the days over which the rainfall events occurred. A second set of wet weather scenarios (MST-W2-Sc1 and MST-W2-Sc2) with higher rainfall totals was extracted from the record, again in the period from the 1/1/ 2012 to the 30/6/2013. The pre and post-upgrade works rainfall totals for this second wet weather scenario were $52.6 \mathrm{~mm}$ and $52.8 \mathrm{~mm}$ respectively and these were reasonably consistent with the $75^{\text {th }}$ percentile $(55.2 \mathrm{~mm})$ of the rainfall amounts in the rainfall record.

Table 2 here

The operational outfalls of the pre-upgrade scenarios were mainly BR_L (Bray long sea outfall) and SH_L (Shanganagh long sea outfalls), while the Bray short sea outfall operated only during the wet weather event $\mathrm{W} 2$ and contributed to 0.12 of the total flow (computed from flow measurements) into the coastal zone. Flow and water quality data at Shanganagh WwTW indicated that the percentage of treated inflow has dropped to $96 \%$ and $93 \%$ during wet weather events W1 and W2 respectively (see pre-upgrade scenarios in Table 2). The Shanganagh long sea outfall (SH_L) has been the sole operational outfall during the dry weather (D) and wet weather (W1) scenarios of the post-upgrade period. Also the level of treatment at Shanganagh WwTW remained at full capacity for all the postupgrade scenarios in Table 2. During the wet weather event W2, SH_L catered for the treatment of 98.5\% of the discharged flow, with only $1.5 \%$ being discharged without treatment from BR_L and BR_S outfalls. The short sea outfall at Shanaganagh was not in operation in the scenarios shown in Table 2 as the generated flow was insufficient to trigger its operation. 


\section{Results and Discussion}

\subsection{Model calibration: Hydrodynamics}

Comparisons between predicted and observed tidal elevations at the five reference gauges showed that the best match was achieved when applying a 1.05 multiplier to the tidal amplitudes and increasing the phase lag by $15^{\circ}$ for both M2 and S2 constituents extracted from the DHI Global Tidal database. Figure 2 shows water levels at two gauges; Dun Laoghaire (DunL in Figure 1) and Howth (HOW in Figure 1) representing the gauges with the best and worst match between simulated and measured water levels respectively. The Root Mean Square of Errors (RMSE) computed over the 33-days simulation period was 4.05 at DunL gauge but 17.1 at Howth. The levels at the Howth gauge, situated on the northern extent of the headland of Howth and just south of the Island of Ireland's Eye, may be affected by a headland tidal race which is common in such geographic settings. To assess the match between amplitudes and phase lags of the decomposed constituents of computed and measured tidal elevations at the five reference gauges ( Figure 1), the Mean Absolute Errors (MAE) and Root Mean Square of Errors - standard deviation ratios (RSR) (see Bennett, et al., 2013; Stow et al., 2009) were computed. The computed MAE (Table 3) demonstrated a significantly improved fit of the calibrated M2 and S2 amplitudes and phase lags compared to those of the DHI database.

The calibration routine of the S2 amplitude yielded a better fit than that for the M2 constituent as indicated by the RSR values of 0.55 and 0.39 for the calibrated amplitudes of the M2 and S2 constituents respectively. However, the calibration of the phase lags resulted in similar levels of accuracy (RSR values of 0.94 and 0.92 for M2 and S2 constituents respectively).

\section{Table 3 here}

\section{Figure 2 here}

The calibration procedure of water velocities demonstrated that the best match between observed and predicted current velocity was achieved when using a Chezy coefficient of 60 for the bottom friction factor. The results of two points $(\mathrm{O}$ and $\mathrm{H} 5)$ are discussed here but similar reasoning applies to the other calibration points within the model domain. Simulated current speeds at the water surface and sea bed were compared to measurements at location $\mathrm{O}$ (Figure 3a). The model replicated well the flooding tide pattern (period before the time of high water), particularly the residual currents around the time of low water (HW-6 h). The simulated results also compared favourably with measured currents but were shown to slightly overestimate the measured surface velocities of the first peak. On the ebb stage of the tide, the model results were shown to fit reasonably well the current speed measurements at the surface and bottom for the period $\mathrm{HW}+4$ to $\mathrm{HW}+6.5 \mathrm{~h}$ but do not match the measurements for the period from $\mathrm{HW}$ to $\mathrm{HW}+4 \mathrm{~h}$. An assessment of the hydrodynamic model skill was performed using the index of agreement developed by Willmott (1981). Perfect agreement 
between model results and observations will yield a skill of one and complete disagreement yields a skill of zero. The model has a skill of 0.84 and 0.6 in predicting the current speed at the seabed and surface respectively (Table 4). These skill values are comparable to the range of values reported in similar modelling studies of tidal waters (see Xing et al., 2013; Hoeke et al. 2013; Wang and Justić, 2009). The findings are also consistent with studies that showed better fit for sea bed velocities than surface velocities (see Levasseur et al., 2007; Warner et al., 2005). A skill of 0.92 for both sea bed and surface current direction demonstrate that the model has adequately replicated the general pattern of the observed current direction which exhibited a north-westerly flow direction during a flood tide and a south-easterly direction during an ebbing tide. The model however has slightly overestimated the flooding tide direction by approximately $20^{\circ}$ and underestimated the ebbing tide direction by approximately $30^{\circ}$ (Figure 3a) but variations of that order have been shown in similar hydrodynamic modelling studies (see Pritchard et al., 2013; Zhang, 2006) and therefore is not uncommon.

At point H5, both observed and simulated velocities were shown to exhibit some noise and this is attributed to the location of sampling point $\mathrm{H} 5$ which is bounded in the north by the south pier of Dun Laoghaire harbour and in the south by Dalkey Head. Nevertheless, the model demonstrated a good fit to the observed velocity pattern (skills of 0.78 and 0.64 for sea bed and surface current speed respectively). The simulated flow direction showed an adequate fit to measurements (skills of 0.94 and 0.92 for sea bed and surface current directions respectively) which showed a change in direction from north-westerly to south-easterly.

\section{Figure 3 here}

Measurements of temperature and salinity (shown as points in Fig. 4) were taken in the water column at point A which is in the vicinity of the Bray harbour mouth and represents the location where the River Dargle discharges into the coastal zone. The measurements taken at the time of mid-flood (HW$3 \mathrm{~h}$ ) showed slightly higher levels of vertical stratification than those taken at the time of high water (HW). This is because a flooding tide pushes the seawater into the harbour thus restricting the River Dargle from discharging into the coastal waters. By the time of high water, the seawater is pushed further into the harbour. Therefore, the stratification at location A due to the freshwater inflow will not be as pronounced around the time of high water. Comparisons of simulated and measured temperature profiles demonstrated a good match particularly around the time of mid-flood. This finding was confirmed by the computed skill statistics which gave values of 0.93 and 0.89 for temperature at times of mid-flood and HW respectively. The simulated salinity profiles yielded a very good fit to measurements (skill values of 0.99 for salinity at the times of mid-flood and HW) albeit slight underestimation of salinity measurements by approximately $2 \%$ was observed at the water surface.

\section{Figure 4 here}


The $E$. coli model was calibrated by varying the $k_{e} H$ coefficient in the Mancini Formula (Equation 8). The best fit between observed and predicted $E$. coli patterns was obtained with a value of 0.6 for the $k_{e} H$ coefficient. The simulated time series of two calibration points ( $\mathrm{N}$ and $\left.\mathrm{G}\right)$ and two validation points $(\mathrm{O}$ and $\mathrm{C}$ ) indicate a unique pattern over the tidal cycle (Figure 5 ). At point $\mathrm{N}$, the simulated $E$. coli concentrations rise quickly from a minimum around the time of low water to reach a peak around the time of mid flood after which they gradually drop again while at point $\mathrm{G}$, the model exhibits a drop in E. coli concentrations during the flooding stage reaching a minimum around the time of high water, then rises again till mid ebb. This difference between the simulated E. coli patterns at $\mathrm{N}$ and $\mathrm{G}$ is attributed to the difference in locations of these sampling points with respect to the discharge outfalls. Therefore, the tidal flow pattern which governs the transport of $E$. coli plumes from the discharge outfalls determines the temporal distribution at these locations. Comparison between simulated and observed E. coli concentrations at $\mathrm{N}$ and $\mathrm{G}$, shows that the model generally captures the order of magnitude of observed concentrations and presents a reasonable match matches semewhat to the observed patterns during at some stages of the tidat mid-flood and around the time of HW cycle at point $\mathrm{N}$ (mid-flood and around the time of HW) and during both ebbing and flooding stages at $\mathrm{G}$ (during both ebbing and flooding stages). It however, underestimates the observed $E$. coli concentrations at mid-flood peak at $\mathrm{N}$ and around low water $(\mathrm{HW}+6 \mathrm{~h})$ at $\mathrm{G}$. At the validation point $\mathrm{O}$, the model presents a good fit to observed $E$. coli concentrations but also underestimates the peak at mid ebb $(\mathrm{HW}+3 \mathrm{~h})$. The fit between observed and predicted concentrations at validation point $\mathrm{C}$ was also reasonable, albeit with some underestimated concentrations around $\mathrm{HW}+4-\mathrm{HW}+7 \mathrm{~h}$. The calibration and validation results of the E. coli model demonstrate a notable discrepancy between observed and simulated $E$. coli concentrations due to the significant random variations of observed $E$. coli concentrations over the course of the tidal cycle. Such random variations of faecal indicator bacteria of the scale observed are not uncommon and have been reported in many previous studies (e.g. Bedri et al., 2013; Quilliam et al., 2011; de Brauwere et al.; 2011; Crowther et al., 2002; EPA, 2010). This random variation has been attributed to a number of factors that include the complex $E$. coli kinetics (see for examples Darrakas, 2002; Gronwold et al., 2011; Bowie et al. 1985) in addition to the high levels of uncertainty associated with the sampling, storage, and enumeration of $E$. coli (Gronewold et al. 2008; McBride et al., 2003; Stapleton et al., 2009). Given this significant variation in observed E. coli levels, accurate predictions of $E$. coli concentrations over the tidal cycle proved to be somewhat challenging.

\section{Figure 5 here}

5.3 Comparison of E. coli water surface distributions pre- and post- upgrade of WwTW 


\subsubsection{Dry Weather conditions}

Figures $6 \mathrm{a}$ and $6 \mathrm{~b}$ show the surface distribution of $E$. coli of Scenarios MST-D-Sc1 and MST-D-Sc2 representing the discharges during dry weather conditions for the period prior to and following the upgrade of the treatment works. The distributions are shown at the time of low water (LW) of a mean spring tide. Figures $6 \mathrm{c}$ and $6 \mathrm{~d}$ show $E$. coli distributions of the same discharge scenarios at $\mathrm{LW}$ during a mean neap tide. Tidal circulation patterns in the study area denote that the south-flowing currents of an ebb tide increase gradually in strength from the time of high water (HW) pushing the pollutant plumes southwards Bray Head. These then are deflected by the headland of Bray Head detaching the plume away from the coastline. Closer to the time of LW, the currents in the outer sea weaken considerably and start to deflect northwards in the near-shore area (Figures 6a and 6c). After the time of LW, the incoming flood tide enters the coastal zone strongly from the south pushing the plume eastwards towards the coastline and northwards towards Dalkey Headland. The flood tide currents are also at their weakest around the time of HW (Figure 7), while ebbing currents start to form closer to the coastline (Figures 7a and 7c). E. coli distributions of Scenarios MST-D-Sc1 and MNT-D-Sc1 (Figures 6 and 7) exhibit higher concentration of E. coli at Bray Beach at LW than HW and higher $E$. coli concentrations at Killiney beach at HW than LW. Also comparisons of distributions of mean spring and mean neap tidal cycles, indicate that a mean spring tide produces a plume of a wider extent. This is due to the stronger currents exhibited by a mean spring tide causing the discharged $E$. coli at the outfall to separate and dissipate at a quicker rate than that of a mean neap cycle. This is particularly evident around the time of $\mathrm{HW}$ (Figures 7a and 7c) where the spring tide plume extends north of Dalkey Island and southwards past Bray head, exhibiting a much larger areal extent than that of a mean neap tide.

\section{Figure 6 here}

The E. coli distributions in Figures 6 and 7 clearly indicate a remarkable improvement to the bathing water quality as a result of the upgraded sewage management system. The plume exhibited by Scenarios MST-D-Sc2 and MNT-D-Sc2 are shown to be of low concentration due to the cessation of raw sewage discharges from the Bray PS (in dry weather conditions) in addition to the adoption of secondary level of treatment (see Table 2). Therefore these scenarios have a quicker rate of dissipation in contrast to those of Scenarios MST-D-Sc1 and MNT-D-Sc1, in which the sewage plumes are shown to extend over a significant extent of the coastal zone, exhibiting high concentrations of $E$. coli in excess of $250 \mathrm{cfu} / 100 \mathrm{ml}$. This is of particular importance given that the $E$. coli limit for "Excellent" quality of $250 \mathrm{cfu} / 100 \mathrm{ml}$ as set out in the revised Bathing Water Directive (2006/7/EC) would be exceeded at both Bray and Killiney beaches. This would have resulted in the loss of the "Blue Flag" status at both beaches during the pre-upgrade period. The Blue Flag award, an 
internationally recognised eco-label, requires bathing waters to comply with the Excellent Standards of Directive 2006/7/EC. Such loss to the Blue Flag status would degrade the beach profile.

\section{Figure 7 here}

\subsubsection{Wet weather conditions}

In Figures 8 -11, E. coli distributions are plotted for wet weather conditions under mean spring tide conditions only, as results in Section 5.3.1 demonstrated that this is more critical than the mean neap tide in terms of the water quality of the coastal area under study.

Figures 8 and 9, show the E. coli distributions of wet weather scenario W1 (Table 2), at four stages of the tidal cycle; mid ebb (ME), low water (LW), mid flood (MF), and high water (HW). Scenario MST-W1-Sc1 shows a larger plume than for Scenario MST-W1-Sc2 and this extends southwards past Bray Head during the ME and LW stages and northwards towards the headland of Dalkey during the MF and HW stages of the tide. The E. coli distributions of Scenario MST-W1-Sc1 show that the concentrations are extremely high (well above the "Sufficient" limit of $500 \mathrm{cfu} / 100 \mathrm{ml}$ set by the bathing water directive) at Bray and Killiney beaches at all four stages of the tidal cycle. Such high concentrations (in excess of $500 \mathrm{cfu} / 100 \mathrm{ml}$ ) imply poor water quality that would result in prohibition of bathing under the revised Bathing Water Directive. The high E. coli concentrations of Scenario MST-W1-Sc1 may be explained by the release of increased volumes of untreated sewage from the Bray pumping station (see Table 2), in addition to the release of partially treated effluent from Shanganagh WwTW. In contrast, the distributions of Scenario MST-W1-Sc2, which represent the post-improvement discharge strategy, show very low E-coli concentrations in the coastal waters, and therefore these will have little impact on the bathing water quality at Bray and Killiney beaches. This is attributed to the insignificant effect that event $\mathrm{W} 1 \mathrm{had}$ on the operation of the upgraded treatment works as the increase in discharge volume was not sufficiently large to trigger the operation of the Bray long outfall (see Table 2).

\section{Figure 8 here \\ Figure 9 here \\ Figure 10 here \\ Figure 11 here}

Figures 10 and 11 show the E. coli distributions of Scenarios MST-W2-Sc1 and MST-W2-Sc2. Scenario MST-W2-Sc1 resulted in extremely high E. coli concentrations at both Bray and Killiney beaches (in excess of $1000 \mathrm{cfu} / 100 \mathrm{ml}$ ) at all four stages of the tide. This would result in a bathing prohibition at the two beaches under Directive 2006/7/EC. The concentrations of Scenario MST-W2Sc2, which represent the post-improvement discharge strategy, are considerably less at Bray beach 
than those of Scenario MST-W2-Sc1, but nevertheless they remain high (in excess of $500 \mathrm{cfu} / 100 \mathrm{ml}$ at ME) due to the release of untreated sewage from both the Bray long and short sea outfalls, the latter of which is in close proximity to Bray beach (see Table 2). Such concentrations of Scenario MSTW2-Sc2 at Bray beach will also have bathing implications under Directive 2006/7/EC. On the other hand, Killiney beach appears to be unaffected by the discharges into the coastal zone.

The E. coli distributions under dry weather conditions (Figures 6 and 7) demonstrate that the upgrade in the treatment works has remarkably improved the bathing water quality. As a consequence, the Blue Flag status at Bray and Killiney beaches would be regained.

The discharge strategy under the new management system is expected to drastically reduce the rainfall-related incidents in which the environmental limits of the Bathing Water Directive are breached. However, significant exceedances to the Bathing Water Quality standard may still occur under wet weather conditions (Figure 8 to Figure 11) at Bray beach due to the storm overflow that may still be discharged through the Bray long and short sea outfalls. In light of the simulated scenario results (Figure 6 to Figure 11), the inclusion of tertiary (Ultra Violet) treatment at Shanganagh STW is unlikely to prevent such incidental breaches to the Bathing Water Standards of Directive 2006/7/EC.

\section{Conclusion}

This study applies a three-dimensional hydrodynamic and water quality model (TELEMAC-3D) to assess the bathing water quality of Bray and Killiney beaches following improvements to the sewage management system under dry and wet weather conditions. The model was first calibrated and validated using hydrodynamic and water quality data and was then used to simulate a number of discharge scenarios corresponding to the periods prior to and following the upgrade of the treatment works under dry and wet weather flows for mean spring and mean neap tidal conditions. The results of dry weather scenarios showed that Scenarios MST-D-Sc1 and MNT-D-Sc2, representing the period prior to the upgrade works, resulted in E. coli distributions at the water surface that exceeded the "Excellent" quality limit of the revised Bathing Water Directive. Such concentrations would result in the loss of the "Blue Flag" status at both Killiney and Bray beaches. In contrast, Scenarios MST-DSc2 and MNT-D-Sc2, of the period following the improvement to the sewage management system, yielded very low concentrations at Bray and Killiney beaches due to the abatement of sewage discharges from Bray PS (under dry weather conditions) in addition to the secondary level of treatment at Shanganagh WwTW. As a result the beaches of Bray and Killiney were of "Excellent" water quality according to the standards of the Bathing Water Directive. E. coli distributions of the wet weather scenarios W1 and W2 showed that the pre-upgrade scenarios MST-W1-Sc1 and MSTW2-Sc1 gave extremely high E. coli concentrations at Bray and Killiney beaches that would result in 
the prohibition of bathing under the revised Bathing Water Directive. Wet weather simulations of the post-upgrade period showed that the rainfall amount of event $\mathrm{W} 1$ was not sufficiently high to trigger the operation of the long and short sea outfalls at Bray, and therefore E. coli concentration at Bray and Killiney of Scenario MST-W1-Sc2 were well below the "Excellent" limit of the Bathing Water Directive. However, event W2 (twice the amount of rainfall of W1) resulted in concentrations that exceeded the "Sufficient" limit of Directive 2006/7/EC at Bray beach due to the discharge of untreated wastewater from the Bray long sea outfall and the short sea outfall which is at a close proximity to Bray beach. On the other hand, Killiney beach appeared to be unaffected by these discharges. The simulation results indicate that while the upgrade works have significantly improved the water quality at Bray and Killiney beaches, failures to comply with the environmental standards of the Bathing water directive at Bray beach may still occur under wet weather conditions due to the storm overflow from the Bray long and short sea outfalls. Therefore, the inclusion of tertiary (Ultra Violet) treatment at Shanganagh WwTW is unlikely to prevent such incidental breaches to the Bathing Water Standards of Directive 2006/7/EC.

\section{Acknowledgements}

The work has been funded by an INTERREG 4A (Ireland and Wales) project. Technical support on the use of the model was provided by DHI (UK and Denmark). Thanks are extended to Mr. Garrett Keane, Dublin Institute of Technology, for the assistance in the calibration of the tidal constituents of the MIKE Global model. The authors wish to acknowledge the help and information provided by Irish EPA, Bray Town Council, Wicklow County Council, and the staff of Shanganagh Wastewater Treatment works.

Figure 1: Study area: (a) TELEMAC-3D mesh of the coastal model with open sea boundaries (top middle), (b) Sampling points in coastal waters_Hydro: hydrodynamic sampling points, WQ: water quality sampling points), (c) Bray harbour showing location of the Bray short sea outfall.

Figure 2: Simulated and observed tidal elevations at (a) Dun Laoghaire tidal gauge, and (b) Howth gauge.

Figure 3: Simulated and observed velocities at the sea bed and water surface at (a) Location $\mathrm{O}$ and (b) Location H5.

Figure 4: Observed and simulated depth profiles of temperature and salinity at Location A.

Figure 5: Simulated and observed E. coli concentrations at the water surface at (a) Location N, (b) Location G, (c) Location O, and (d) Location C. 
Figure 6: Surface distributions of E. coli of the dry weather scenario (D) at the time of Low Water: (a) pre-upgrade scenario - Mean Spring Tide, (b) post-upgrade scenario - Mean Spring Tide, (c) preupgrade scenario - Mean Neap tide, (b) post-upgrade scenario - Mean Neap Tide

Figure 7: Surface distributions of $E$. coli of the dry weather scenario (D) at the time of High Water: (a) pre-upgrade scenario - Mean Spring Tide, (b) post-upgrade scenario - Mean Spring Tide, (c) preupgrade scenario - Mean Neap tide, (b) post-upgrade scenario - Mean Neap Tide

Figure 8: Surface distributions of E. coli of the wet weather scenario (W1): (a) pre-upgrade scenario at Mid ebb, (b) post-upgrade scenario - at Mid ebb, (c) pre-upgrade scenario - at the time of Low Water, (d) post-upgrade scenario - at the time of Low Water.

Figure 9: Surface distributions of $E$. coli of the wet weather scenario (W1): (a) pre-upgrade scenario at Mid Flood, (b) post-upgrade scenario - at Mid Flood, (c) pre-upgrade scenario - at the time of High Water, (d) post-upgrade scenario - at the time of High Water.

Figure 10: Surface distributions of E. coli of the wet weather scenario (W2): (a) pre-upgrade scenario - at Mid ebb, (b) post-upgrade scenario - at Mid ebb, (c) pre-upgrade scenario - at the time of Low Water, (d) post-upgrade scenario - at the time of Low Water.

Figure 11: Surface distributions of E. coli of the wet weather scenario (W2): (a) pre-upgrade scenario - at Mid Flood, (b) post-upgrade scenario - at Mid Flood, (c) pre-upgrade scenario - at the time of High Water, (d) post-upgrade scenario - at the time of High Water.

Table 1: Data sources

Table 2: Simulated discharge scenarios. BR_L: Bray PS - long sea outfall, BR_S: Bray PS - short sea outfall, SH_L: Shanganagh WwTW - long sea outfall, Sec.: secondary treatment.

Table 3: Mean Average Errors (MAE) and Root Mean Square of Errors - Standard Ratio (RSR) between predicted and measured amplitudes and phase lags at the reference tidal gauges

Table 4: Predictive skills for the time series of current speed and direction

\section{References}

Bedri, Z., Bruen, M., Dowley, A., Masterson, B., 2011. A Three-Dimensional Hydro-Environmental Model of Dublin Bay. Environ Model Assess 16, 369-384.

Bedri, Z., Bruen, M., Dowley, A., Masterson, B., 2013. Environmental consequences of a power plant shut-down: A three-dimensional water quality model of Dublin Bay. Marine Pollution Bulletin 71, $117-128$.

Bennett, N.D., Croke, B.F.W., Guariso, G., Guillaume, J.H.A., Hamilton, S.H., Jakeman, A.J., Marsili-Libelli, S., Newham, L.T.H., Norton, J.P., Perrin, C., Pierce, S.A., Robson, B., Seppelt, R., Voinov, A.A., Fath, B.D., Andreassian, V., 2013. Characterising performance of environmental models. Environmental Modelling \& Software 40, 1-20. 
Bougeard, M., LE Saux, J.-C., Pe'renne, N., Baffaut, C., Robin, M., Pommepuy, M., 2011. Modeling of Escherichia coli fluxes on a catchment and the impact on caostal wate and shefflish quality. Journal of the american water resources association 47, 350-366.

Bowie, G.L., Mills, W.B., Porcella, D.B., Campbell, C.L., Pagenkopf, J.R., Rupp, G.L., Johnson, K.M., Chan, P.W.H., Gehrini, S.A., 1985. Rates, constants, and kinetics formulations in surface water quality modelling, 2 ed., U.S. EPA Environmental Research Laboratory.

Bruen, M.P., Chawla, R., Crowther, J., Francis, C.A., Kay, D., Masterson, B.F., O'Connor, P.E., Parmentier, B., Stokes, J., Thorp, M.B., Watkins, J., Wyer, M.D., 2001 Achieving EU Standards in Recreational Waters, Maritime Ireland/Wales INTERREG Report No. 6, The Marine Institute, Dublin.

Bustamante, M., Bevilacqua, S., Tajadura, J., Terlizzi, A., Saiz-Salinas, J.I., 2012. Detecting human mitigation intervention: Effects of sewage treatment upgrade on rocky macrofaunal assemblages. Marine Environmental Research 80, 27-37.

Chan, S.N., Thoe, W., Lee, J.H.W., 2013. Real-time forecasting of Hong Kong beach water quality by 3D deterministic model. Water Research 47, 1631-1647.

Chang, W.K., Ryu, J., Yi, Y., Lee, W.-C., Lee, C.-W., Kang, D., Lee, C.-H., Hong, S., Nam, J., Khim, J.S., 2012. Improved water quality in response to pollution control measures at Masan Bay, Korea. Marine Pollution Bulletin 64, 427-435.

Christoulas, D.G., Andreadakis, A.D., 1995. Application of the eu bathing water directive to the design of marine sewage disposal systems. Water Science and Technology 32, 53-60.

Crisp, J., 1976. Survey of environmental conditions in the Liffey Estuary and Dublin Bay, Summary, Report to the ESB and Dublin Port and Docks Board. University College of North Wales, Bangor.

Crowther, J., Kay, D., Wyer, M.D., 2002. Faecal-indicator concentrations in waters draining lowland pastoral catchments in the UK: relationships with land use and farming practices. Water Research 36, 1725-1734.

Darakas, E., 2002. E. coli kinetics-effect of temperature on the maintenance and respectively the decay phase. Environmental Monitoring and Assessment 78, 101-110.

de Brauwere, A., de Brye, B., Servais, P., Passerat, J., Deleersnijder, E., 2011. Modelling Escherichia coli concentrations in the tidal Scheldt river and estuary. Water Research 45, 2724-2738.

DHI, 2013. MIKE21 Tidal analysis and prediction module. Scientific documentation: DHI Group, Horshølme, Denmark.

EC, 2006a. Directive 2006/113/EC of the European Parliament and of the Council of 12 December 2006 on the quality required of shellfish waters.

EC, 2006b. Council Directive 2006/7/EC of 15 February 2006 concerning the management of bathing water quality and repelling Directive 76/160/EEC.

EEC, 1976. Council Directive 76/160/EEC of 8 December 1975 concerning the quality of bathing water. 
EEC, 1991. Council Directive 91/271/EEC of 21 May 1991 concerning urban waste-water treatment.

EPA, 2010. Sampling and consideration of variability (Temporal and Spatial) for monitoring of recreational waters. US Environmental Protection Agency.

García-Barcina, J.M., González-Oreja, J.A., De la Sota, A., 2006. Assessing the improvement of the Bilbao estuary water quality in response to pollution abatement measures. Water Research 40, 951960.

Georgiou, S., Bateman, I.J., 2005. Revision of the EU Bathing Water Directive: economic costs and benefits. Marine Pollution Bulletin 50, 430-438.

Gronewold, A.D., Borsuk, M.E., Wolpert, R.L., Reckhow, K.H., 2008. An assessment of fecal indicator bacteria-based water quality standards. Environmental Science \& Technology 42, 46764682.

Gronewold, A.D., Myers, L., Swall, J.L., Noble, R.T., 2011. Addressing uncertainty in fecal indicator bacteria dark inactivation rates. Water Research 45, 652-664.

Hall, P., Davies, A., 2007. A three-dimensional finite-element model of wind effects upon higher harmonics of the internal tide. Ocean Dynamics 57, 305-323.

Hervouet, J., 2007. Hydrodynamics of free surface flows: Modelling with the finite element method. Wiley, Chichester.

Hewett, T., 2007. Implications of the revision to the bathing water directive for local authorities in the Solent. Marine Policy 31, 628-631.

Hoeke, R.K., Storlazzi, C.D., Ridd, P.V., 2013. Drivers of circulation in a fringing coral reef embayment: A wave-flow coupled numerical modeling study of Hanalei Bay, Hawaii. Continental Shelf Research 58, 79-95.

Hynes, S., Tinch, D., Hanley, N., 2013. Valuing improvements to coastal waters using choice experiments: An application to revisions of the EU Bathing Waters Directive. Marine Policy 40, 137144.

ISO, 2000. Water quality - Detection and enumeration of Escherichia coli and coliform bacteria. Part 1: Membrane filtration method. ISO 9308-1:2000(E). International Organization for Standardization. Geneva, Switzerland.

Kashefipour, S.M., Lin, B., Falconer, R.A., 2006. Modelling the fate of faecal indicators in a coastal basin. Water Research 40, 1413-1425.

Kashefipour, S.M., Lin, B., Harris, E., Falconer, R.A., 2002. Hydro-environmental modelling for bathing water compliance of an estuarine basin. Water Research 36, 1854-1868.

Levasseur, A., Shi, L., Wells, N.C., Purdie, D.A., Kelly-Gerreyn, B.A., 2007. A three-dimensional hydrodynamic model of estuarine circulation with an application to Southampton Water, UK. Estuarine, Coastal and Shelf Science 73, 753-767.

Mancini, J.L., 1978. Numerical estimates of coliform mortality rates under various conditions. Journal of the Water Pollution Control Federation 50, 2477-2484. 
Mansfield, M., 1992. Field studies of currents and dispersion, Dublin Bay Water Quality Management Plan. Environmental Research Unit, Ireland.

Marques, W.C., Fernandes, E.H., Monteiro, I.O., Möller, O.O., 2009. Numerical modeling of the Patos Lagoon coastal plume, Brazil. Continental Shelf Research 29, 556-571.

Martín, I., Betancort, J.R., Pidre, J.R., 2007. Contribution of non-conventional technologies for sewage treatment to improve the quality of bathing waters (ICREW project). Desalination 215, 82-89.

McBride, G.B., McWhirter, J.L., Dalgety, M.H., 2003. Uncertainty in most probable number calculations for microbiological

assays. Journal of AOAC International 86, 1084 - 1088.

Munk, W., Anderson, E.R., 1948. Notes on the theory of the thermocline. J. Mar. Res. 3, 276-295.

Pritchard, D., Savidge, G., Elsäßer, B., 2013. Coupled hydrodynamic and wastewater plume models of Belfast Lough, Northern Ireland: A predictive tool for future ecological studies. Marine Pollution Bulletin 77, 290-299.

Quilliam, R., Clements, K., Duce, C., Cottrill, S., Malham, S., Jones, D., 2011. Spatial variation of waterborne Escherichia coli - implications for routine water quality monitoring. Journal of Water Health 9, 734-737.

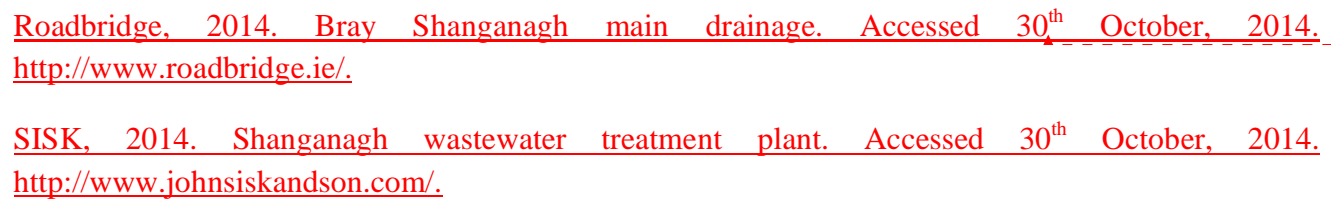

Sato, T., Tonoki, K., Yoshikawa, T., Tsuchiya, Y., 2006. Numerical and hydraulic simulations of the effect of Density Current Generator in a semi-enclosed tidal bay. Coastal Engineering 53, 49-64.

Schnauder, I., Bockelmann-Evans, B., Lin, B., 2007. Modelling faecal bacteria pathways in receiving waters, Proceedings of the ICE - Maritime Engineering, pp. 143-153.

Smagorinsky, J., 1963. General circulation experimens with the primitive equations. Monthly Weather Review 91, 99-164.

Stapleton, C.M., Kay, D., Wyer, M.D., Davies, C., Watkins, J., Kay, C., McDonald, A.T., Porter, J., Gawler, A., 2009. Evaluating the operational utility of a Bacteroidales quantitative PCR-based MST approach in determining the source of faecal indicator organisms at a UK bathing water. Water Research 43, 4888-4899.

Stow, C.A., Jolliff, J., McGillicuddy Jr, D.J., Doney, S.C., Allen, J.I., Friedrichs, M.A.M., Rose, K.A., Wallhead, P., 2009. Skill assessment for coupled biological/physical models of marine systems. Journal of Marine Systems 76, 4-15.

Taylor, D.I., 2010. The Boston Harbor Project, and large decreases in loadings of eutrophicationrelated materials to Boston Harbor. Marine Pollution Bulletin 60, 609-619. 
Thupaki, P., Phanikumar, M.S., Beletsky, D., Schwab, D.J., Nevers, M.B., Whitman, R.L., 2010. Budget Analysis of Escherichia coli at a Southern Lake Michigan Beach. Environmental Science and Technology 44, 1010 - 1016.

Wang, L., Justić, D., 2009. A modeling study of the physical processes affecting the development of seasonal hypoxia over the inner Louisiana-Texas shelf: Circulation and stratification. Continental Shelf Research 29, 1464-1476.

Warner, J.C., Geyer, W.R., Lerczak, J.A., 2005. Numerical modeling of an estuary: A comprehensive skill assessment. Journal of Geophysical Research: Oceans 110, C05001.

Willmott, C.J., 1981. ON THE VALIDATION OF MODELS. Physical Geography 2, 184-194.

Xing, Y., Ai, C., Jin, S., 2013. A three-dimensional hydrodynamic and salinity transport model of estuarine circulation with an application to a macrotidal estuary. Applied Ocean Research 39, 53-71.

Xu, J., Lee, J.H.W., Yin, K., Liu, H., Harrison, P.J., 2011. Environmental response to sewage treatment strategies: Hong Kong's experience in long term water quality monitoring. Marine Pollution Bulletin 62, 2275-2287.

Zhang, Q.Y., 2006. Comparison of two three-dimensional hydrodynamic modeling systems for coastal tidal motion. Ocean Engineering 33, 137-151. 
Table 1: Data sources

\begin{tabular}{|l|l|l|}
\hline Data Type & Purpose & Source Details \\
\hline Bathymetric data & Construction of model mesh & $\begin{array}{l}\text { Previous bathymetric surveys and Admiralty } \\
\text { Charts }\end{array}$ \\
\hline $\begin{array}{l}\text { Temperature and Salinity } \\
\text { data }\end{array}$ & Drive hydrodynamics & $\begin{array}{l}\text { Depth profiles of temperature and salinity at } \\
\text { the mouth of Bray harbour (location A) at } \\
\text { different stages of the tidal cycle }\end{array}$ \\
\hline Velocity measurements & $\begin{array}{l}\text { Calibration and validation of } \\
\text { hydrodynamics }\end{array}$ & $\begin{array}{l}\text { At depth measurements of current speed and } \\
\text { direction spanning full neap and spring tides, } \\
\text { taken at a number of points (Figure 1) }\end{array}$ \\
\hline Tidal elevations & $\begin{array}{l}\text { Drive and calibrate hydrodynamic } \\
\text { model }\end{array}$ & $\begin{array}{l}\text { MIKE global tidal database (DHI, 2013) } \\
\text { Water level at five reference tide gauges } \\
\text { (Figure 1) }\end{array}$ \\
\hline $\begin{array}{l}\text { Water quality measurements } \\
\text { (E. coli) }\end{array}$ & Drive hydrodynamic model & $\begin{array}{l}\text { Time series of wind speed and direction at } \\
\text { Bray weather station (Figure 1) }\end{array}$ \\
\hline $\begin{array}{l}\text { Wind calibrate water quality model } \\
\text { Dray PS and Shanganagh WwTW: } \\
\text { measurements of flow and E. coli } \\
\text { concentrations obtained from local } \\
\text { authorities }\end{array}$ \\
$\begin{array}{l}\text { Measurements of E. coli concentrations } \\
\text { spanning the full tidal cycle (approximately } \\
\text { 12 hours), taken at an hourly interval at a } \\
\text { depth of 0.5m below the the-water surface at } \\
\text { 11 severallocations WQ in fFigure 1). }\end{array}$ \\
\hline
\end{tabular}


Table 2: Simulated discharge scenarios. BR_L: Bray PS - long sea outfall, BR_S: Bray PS - short sea outfall, SH_L: Shanganagh STW - long sea outfall, Sec.: secondary treatment.

\begin{tabular}{|c|c|c|c|c|c|c|c|c|}
\hline \multirow{3}{*}{ Scenario } & \multirow{3}{*}{ Tide } & \multirow{3}{*}{$\begin{array}{l}\text { Rainfall } \\
\text { amount } \\
(\mathrm{mm})\end{array}$} & \multicolumn{6}{|c|}{ Operational Outfalls } \\
\hline & & & \multicolumn{3}{|c|}{$\begin{array}{l}\text { contribution of outfall ( } \% \\
\text { of total flow into coastal } \\
\text { zone) }\end{array}$} & \multicolumn{3}{|c|}{$\begin{array}{l}\text { Level of Treatment (\% of } \\
\text { treated flow) }\end{array}$} \\
\hline & & & BR_L & BR_S & SH_L & BR_L & BR_S & SH_L \\
\hline \multicolumn{9}{|l|}{ Pre-upgrade } \\
\hline MST-D-Sc1 & MST & 0 & $35 \%$ & & $65 \%$ & None & & Sec. $(100 \%)$ \\
\hline MNT-D-Sc1 & MNT & 0 & $35 \%$ & & $65 \%$ & None & & Sec. $(100 \%)$ \\
\hline MST-W1-Sc1 & MST & 25 & $39 \%$ & & $61 \%$ & None & & Sec. $(96 \%)$ \\
\hline MST-W2-Sc1 & MST & 52.6 & $25 \%$ & $12 \%$ & $63 \%$ & None & None & Sec. $(93 \%)$ \\
\hline \multicolumn{9}{|l|}{ Post-upgrade } \\
\hline MST-D-Sc2 & MST & 0 & & & $100 \%$ & & & Sec. $(100 \%)$ \\
\hline MNT-D-Sc2 & MNT & 0 & & & $100 \%$ & & & Sec. $(100 \%)$ \\
\hline MST-W1-Sc2 & MST & 22.8 & & & $100 \%$ & & & Sec. $(100 \%)$ \\
\hline MST-W2-Sc2 & MST & 52.8 & $1 \%$ & $0.50 \%$ & $98.50 \%$ & None & None & Sec. $(100 \%)$ \\
\hline
\end{tabular}


Table 3: Mean Average Errors (MAE) and Root Mean Square of Errors - Standard Ratio (RSR) between predicted and measured amplitudes and phase lags at the reference tidal gauges

\begin{tabular}{lcccccc}
\hline & \multicolumn{2}{c}{ M2 } & & \multicolumn{2}{c}{ S2 } \\
\cline { 2 - 3 } \cline { 5 - 6 } & Amp & Phase & & Amp & Phase \\
\hline MAE & & & & & \\
DHI Global Tidal database & 0.065 & 15.16 & & 0.0206 & 17.53 \\
Calibrated constituents & 0.03 & 5.67 & & 0.004 & 6.35 \\
& & & & & \\
RSR & & & & & 1.87 & 1.96 \\
DHI Global Tidal database & 1.15 & 2.24 & & 0.39 & 0.92 \\
Calibrated constituents & 0.55 & 0.94 & & & \\
\hline
\end{tabular}


Table 4: Predictive skills for the time series of current speed and direction

\begin{tabular}{lcccc}
\hline \multirow{2}{*}{ Location } & \multicolumn{2}{c}{ Current Speed } & \multicolumn{2}{c}{ Current Direction } \\
\cline { 2 - 5 } & Seabed & Surface & Seabed & Surface \\
Location O & 0.84 & 0.6 & 0.92 & 0.92 \\
Location H5 & 0.78 & 0.64 & 0.94 & 0.92 \\
\hline
\end{tabular}




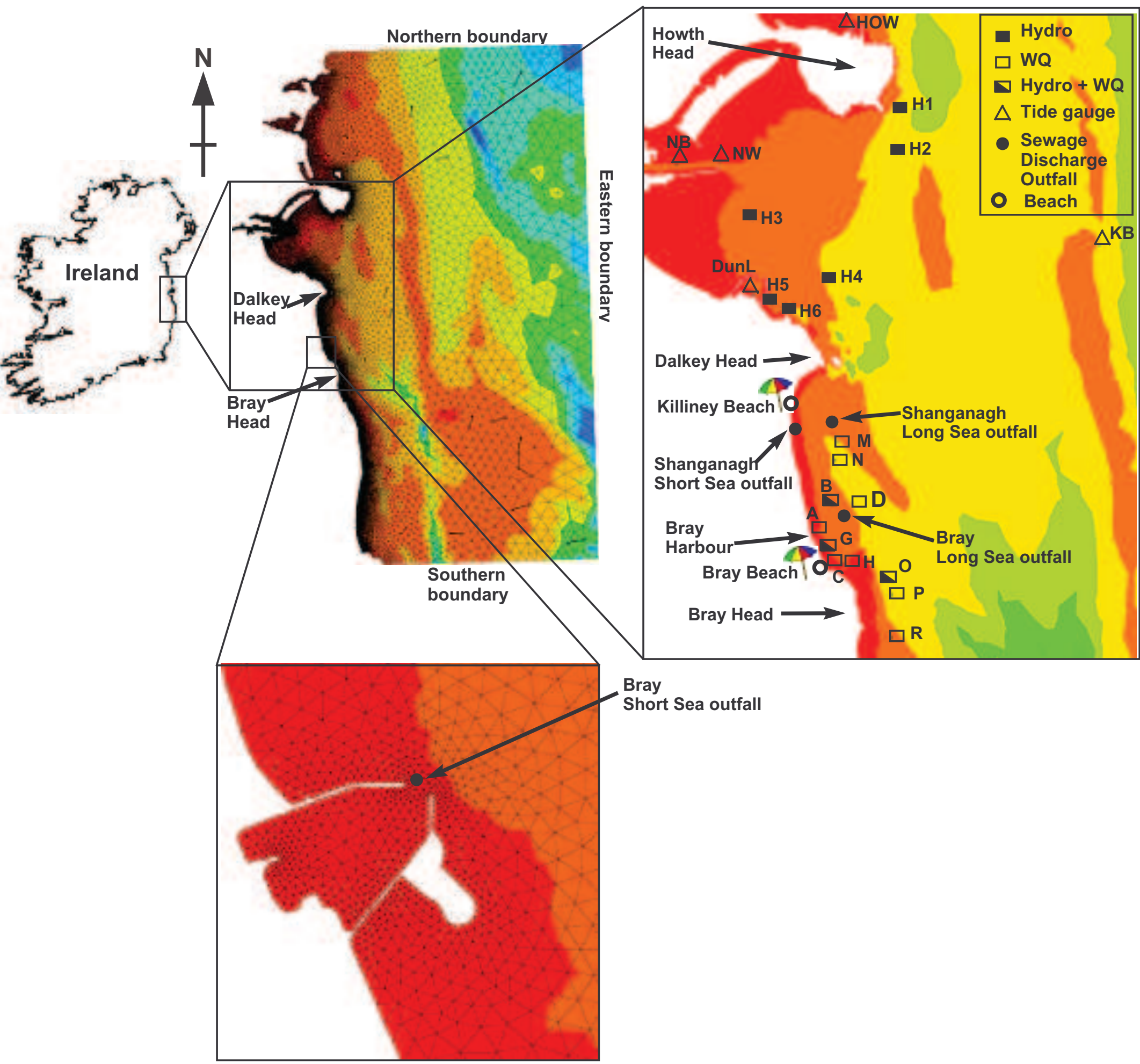




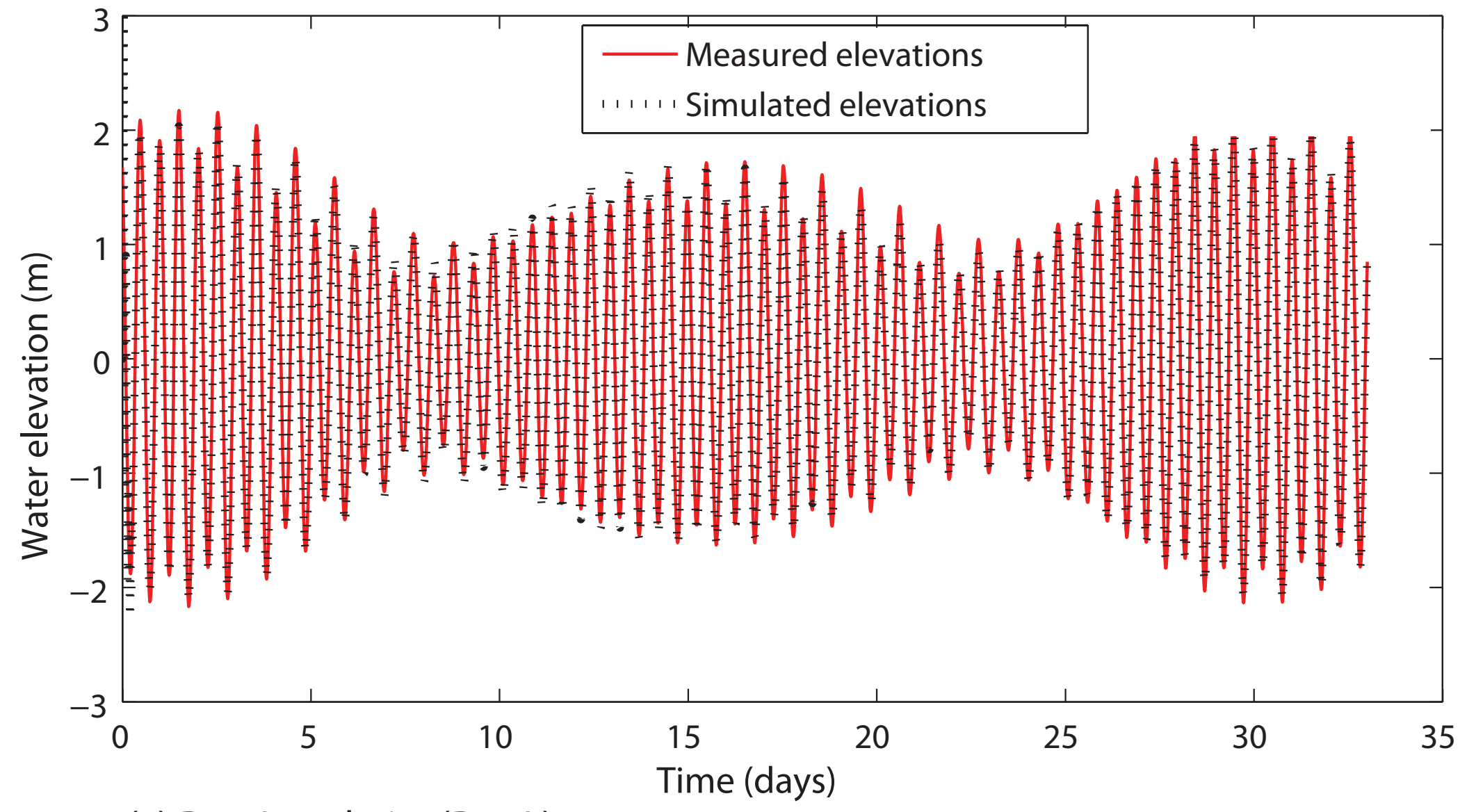

(a) Dun Laoghaire (DunL) gauge

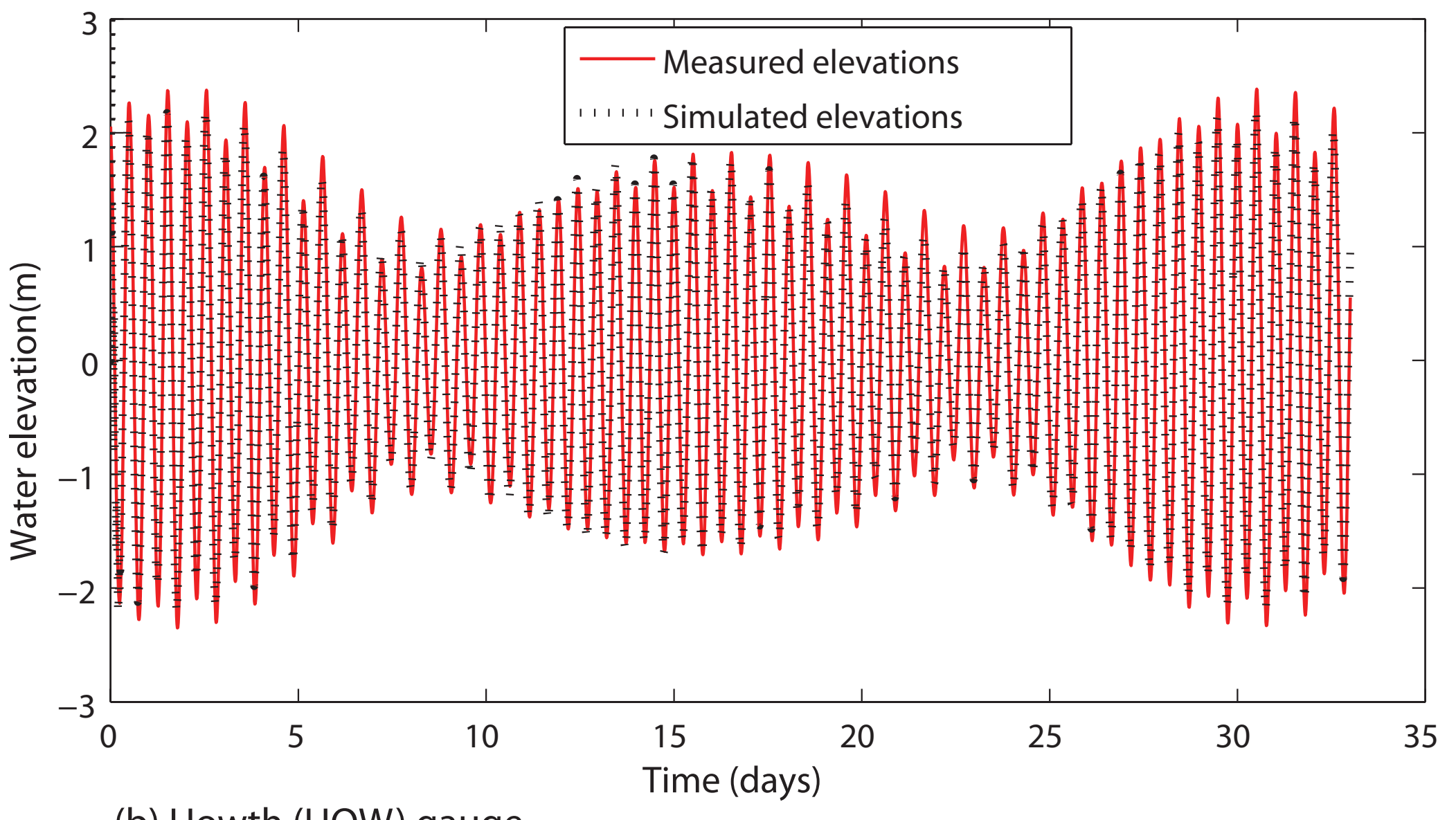

(b) Howth (HOW) gauge 

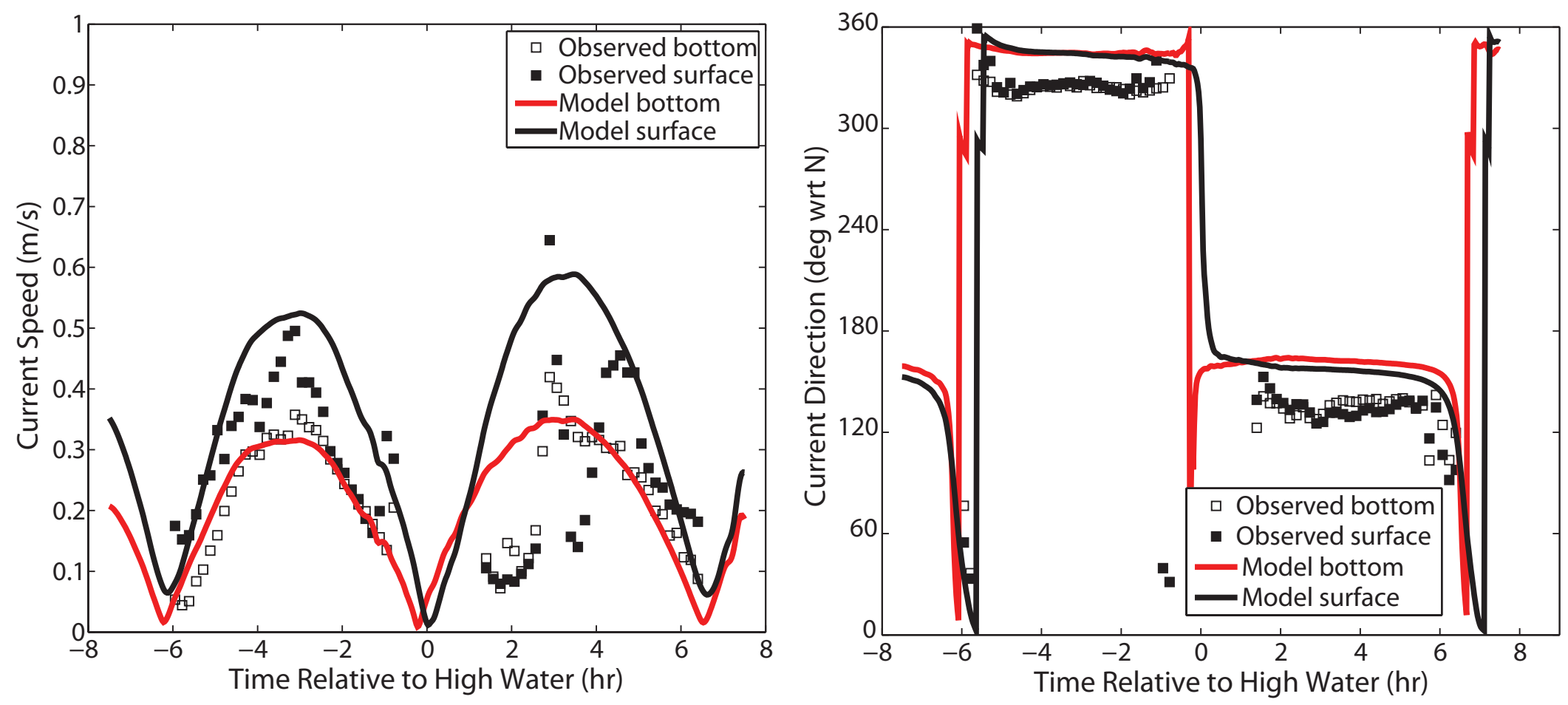

(a) Location $\mathrm{O}$
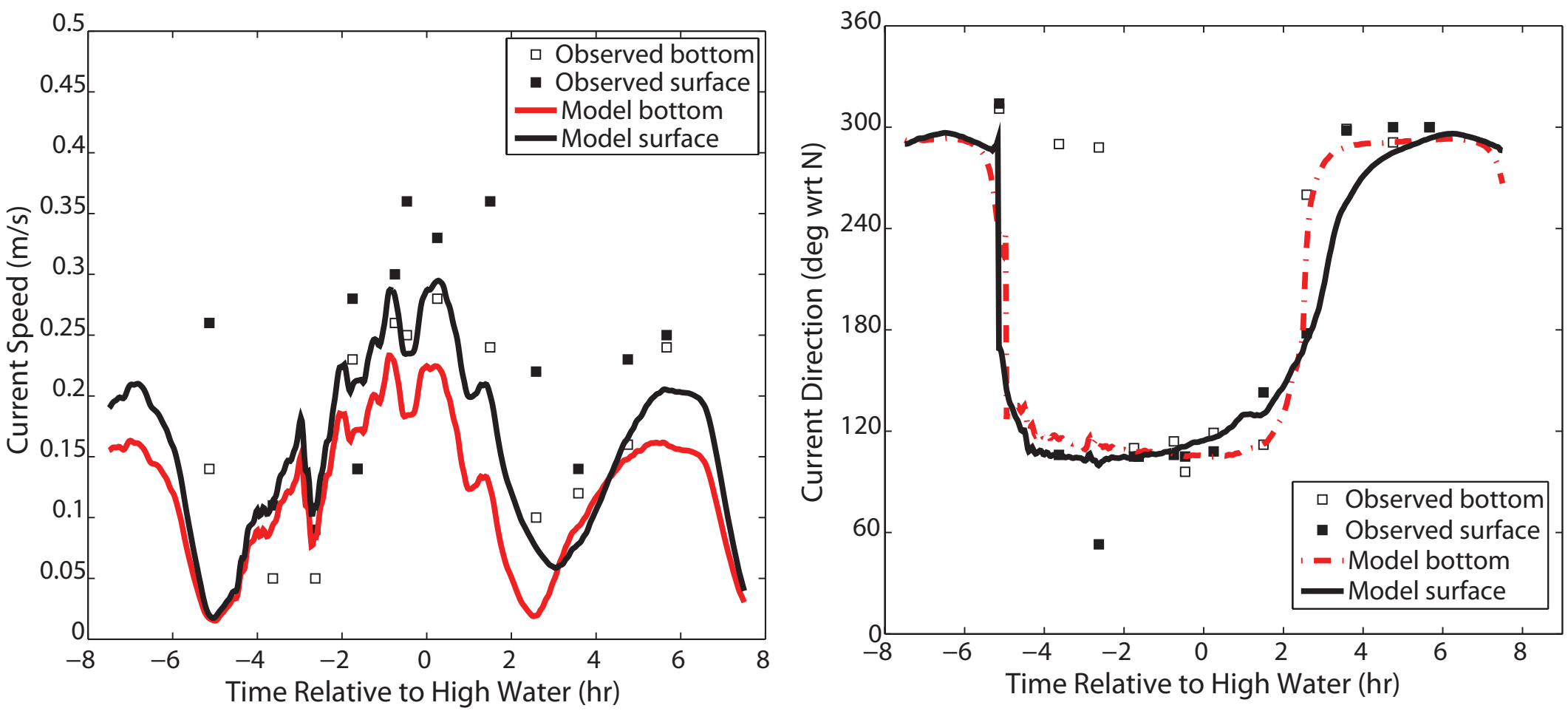

(b) Location $\mathrm{H} 5$ 

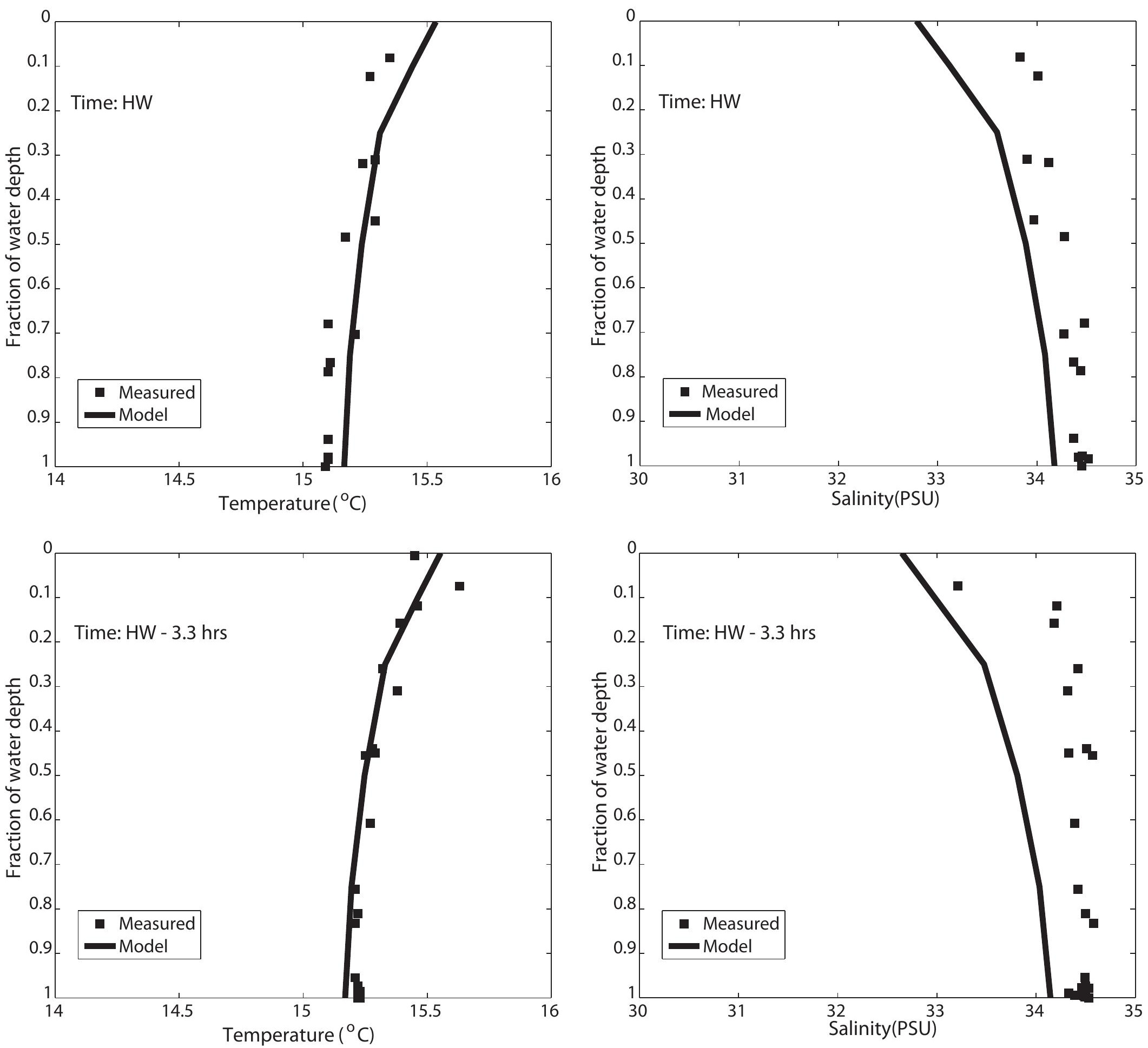


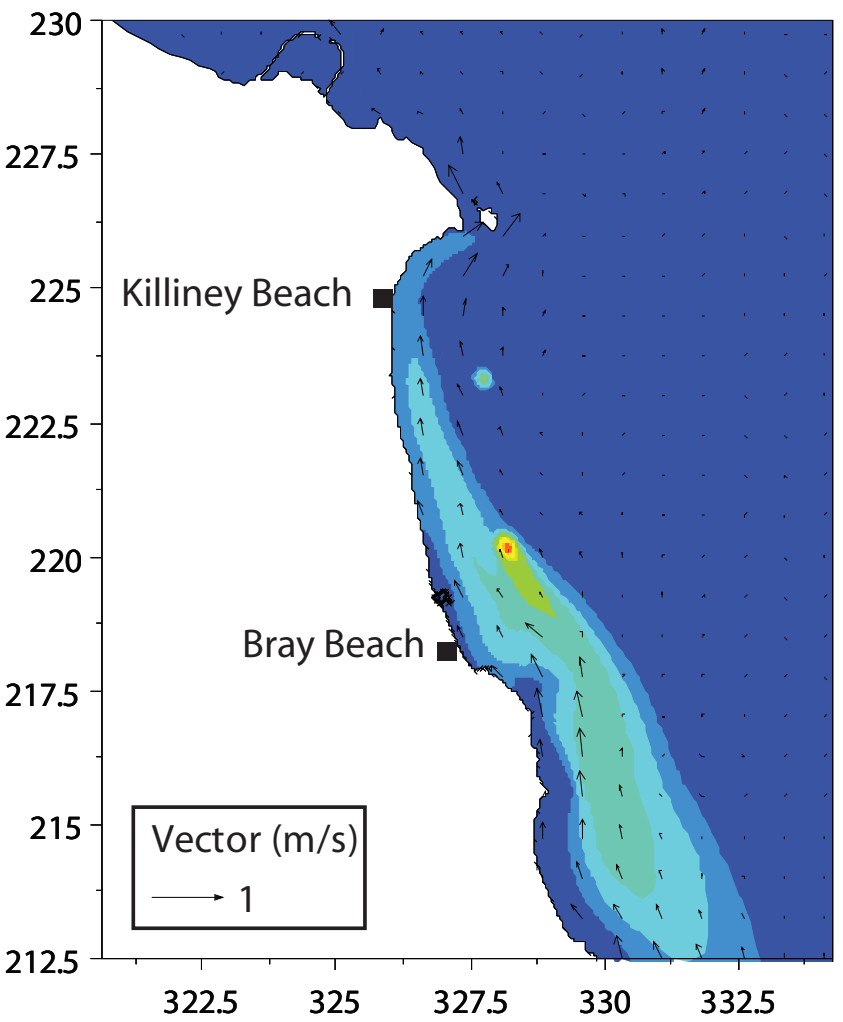

(a) MST-D - Sc1

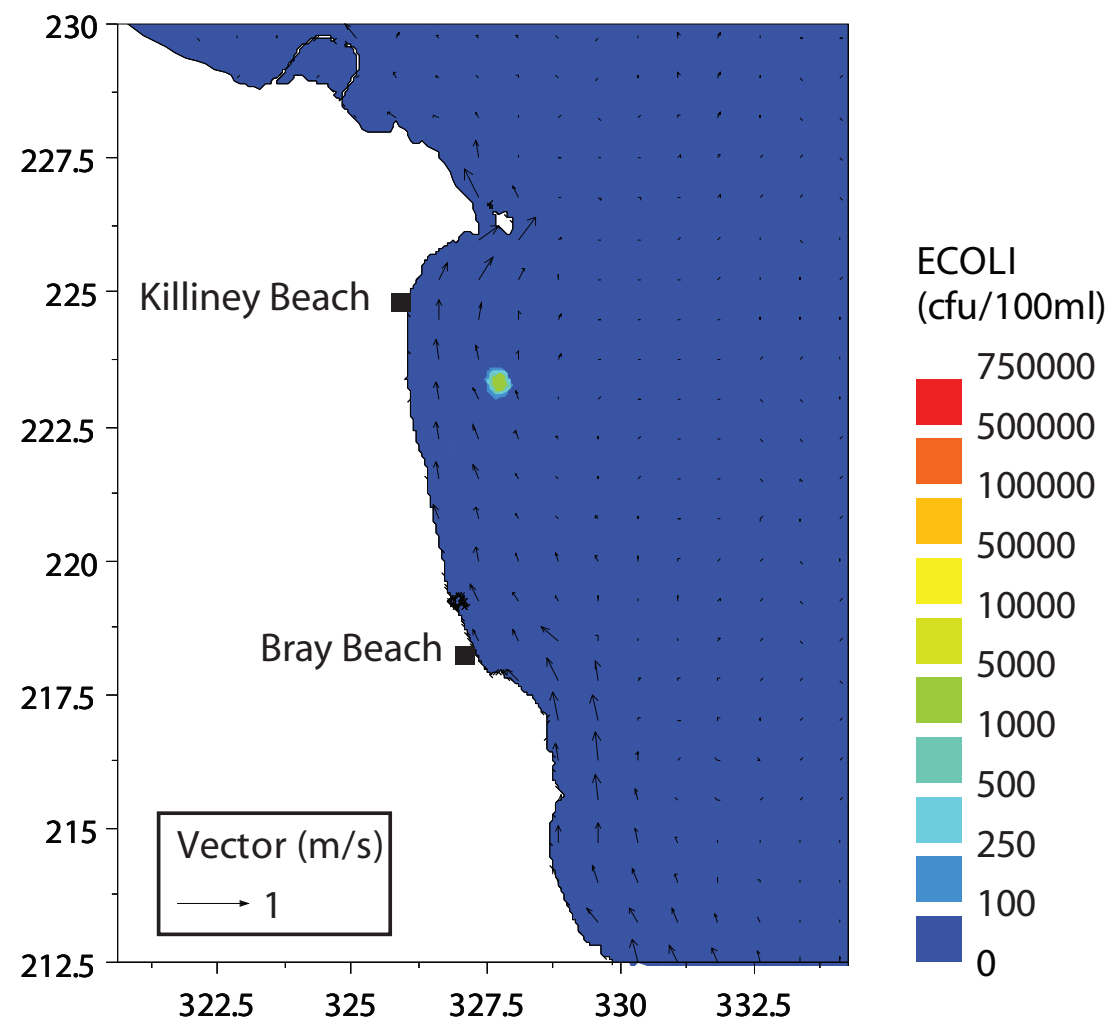

(b) MST-D - Sc2
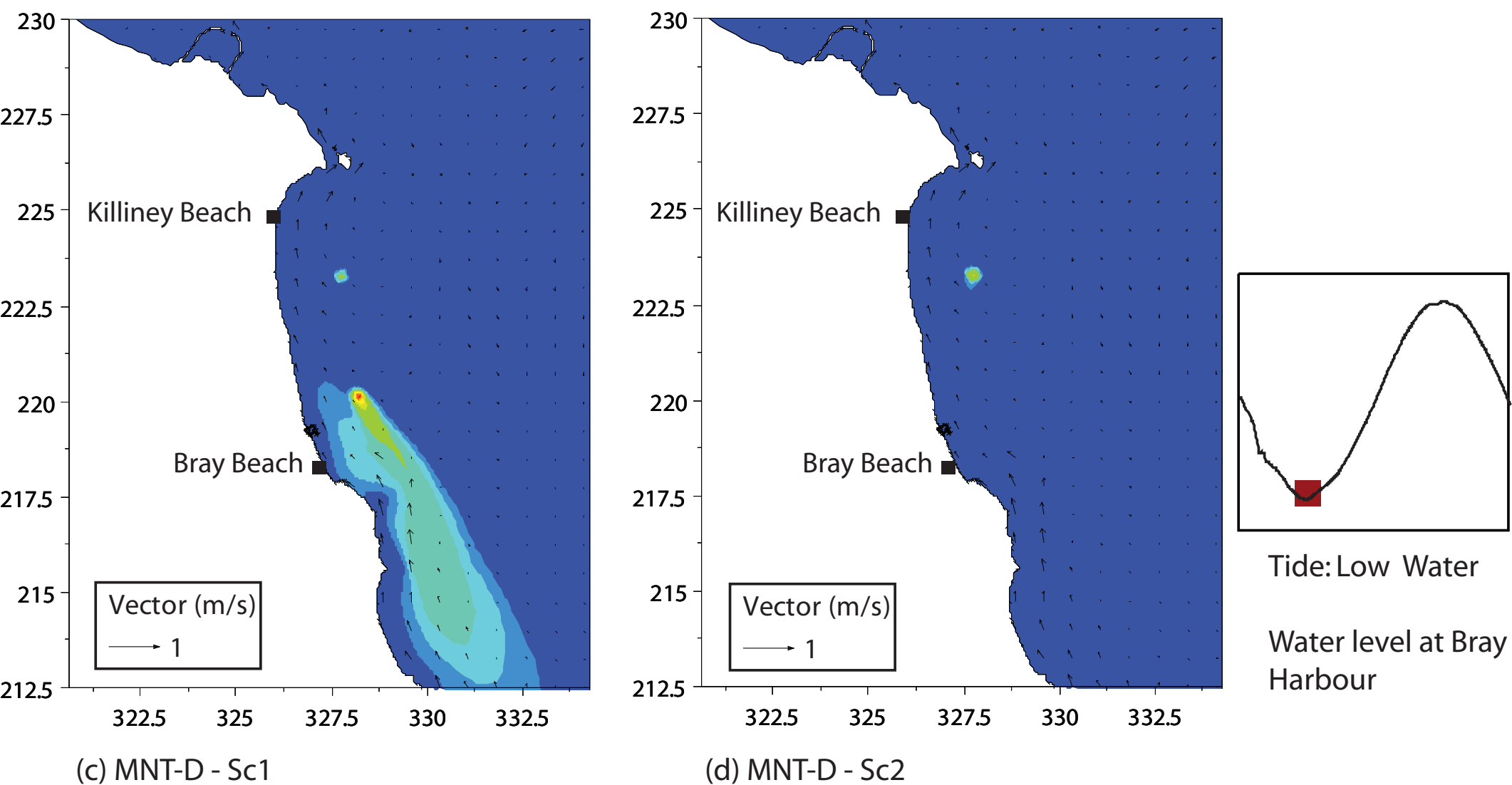

(d) MNT-D - Sc2 

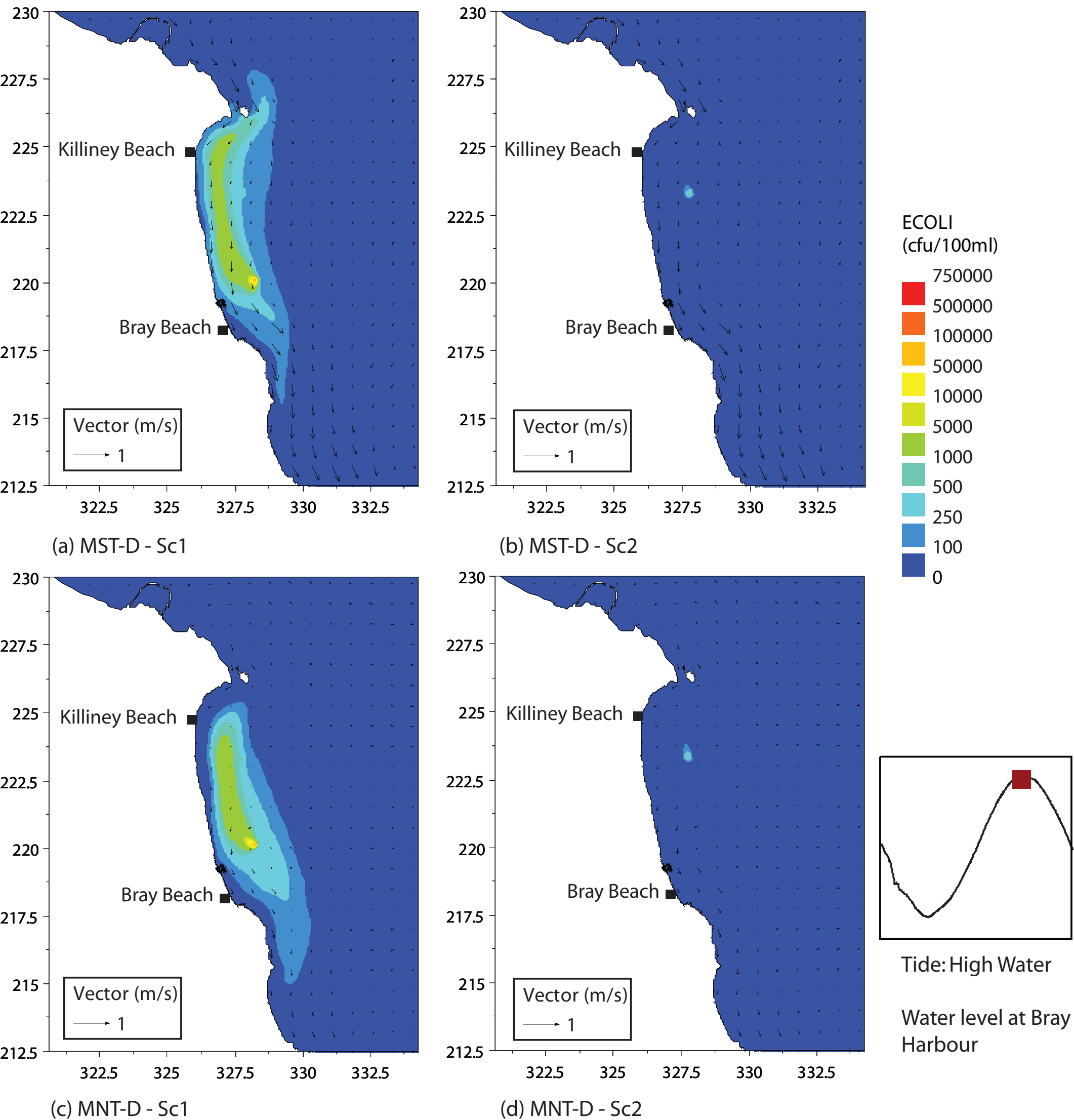

(c) MNT-D - Sc1

(d) MNT-D - Sc2 


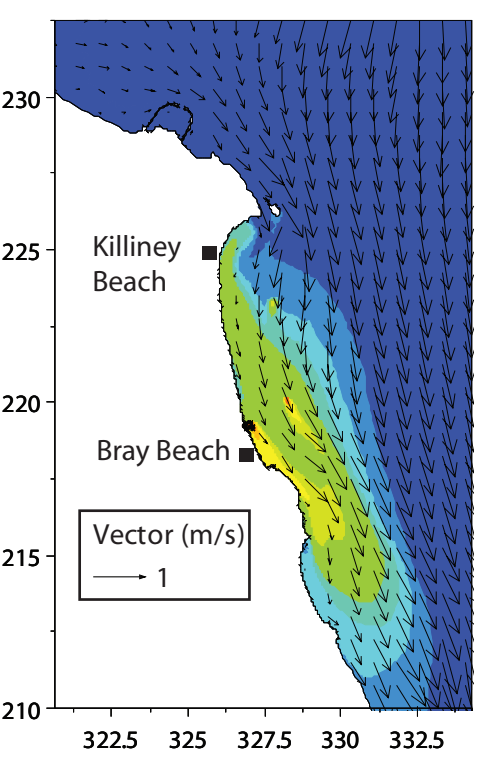

(a) MST-W2 - Sc1

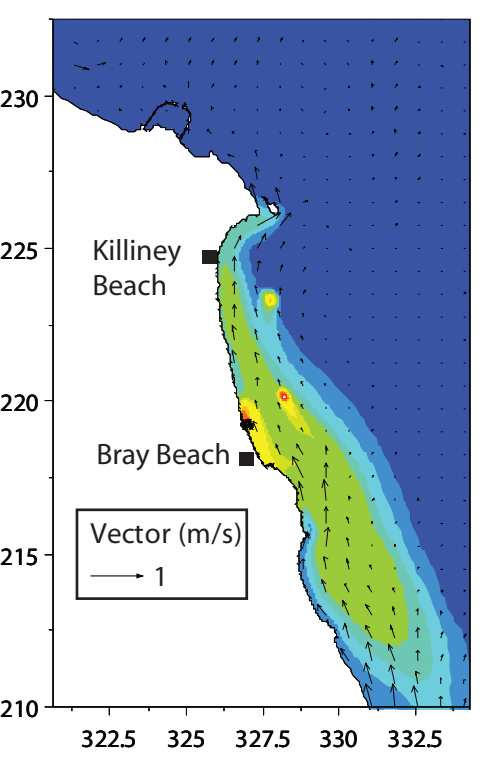

(c) MST-W2 - Sc1
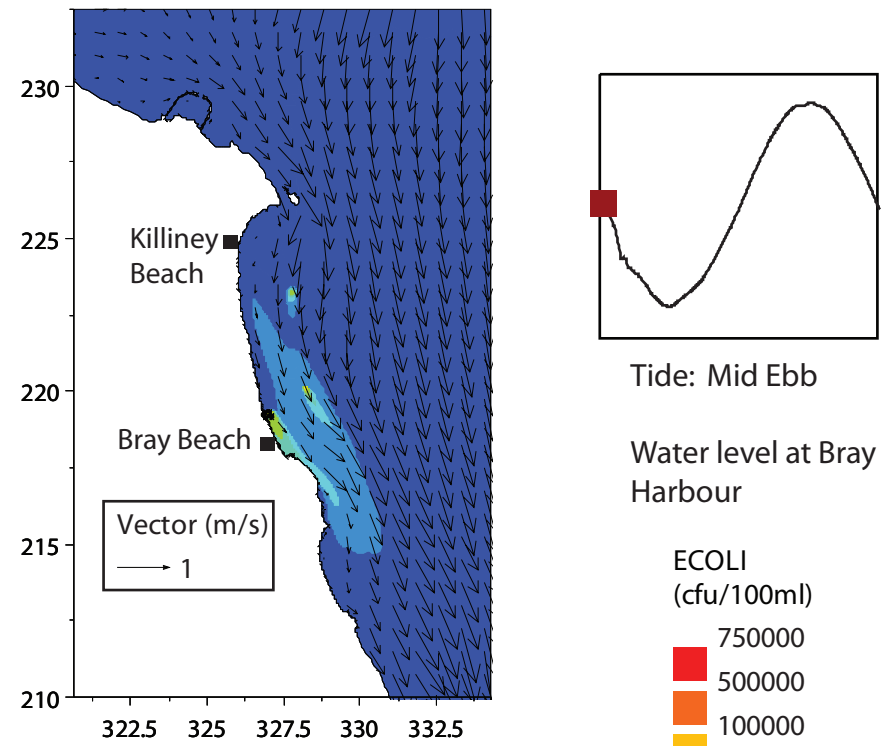

Tide: Mid Ebb

Water level at Bray Harbour

ECOLI (cfu/100ml)

750000
500000
100000

(b) MST-W2 - Sc2

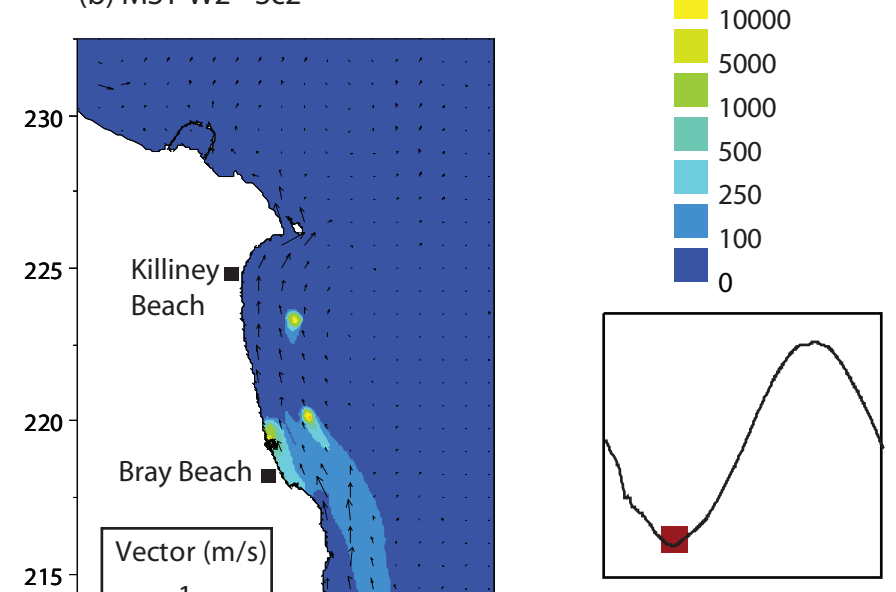

Tide: Low Water

Water level at Bray Harbour

(d) MST-W2 - Sc2 


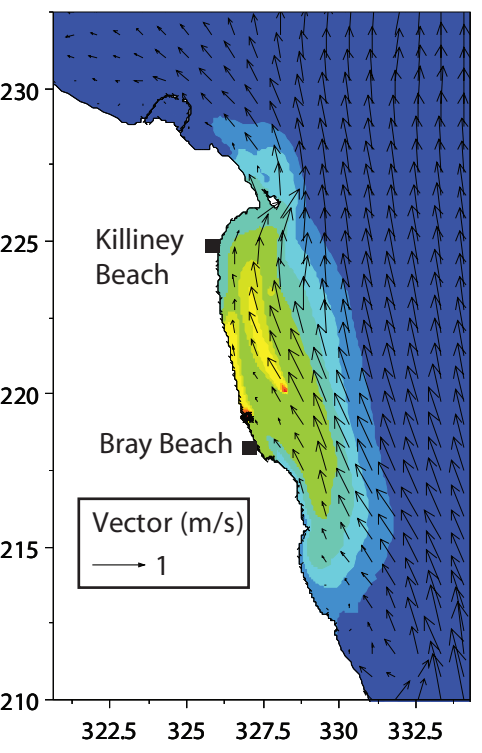

(a) MST-W2 - SC1

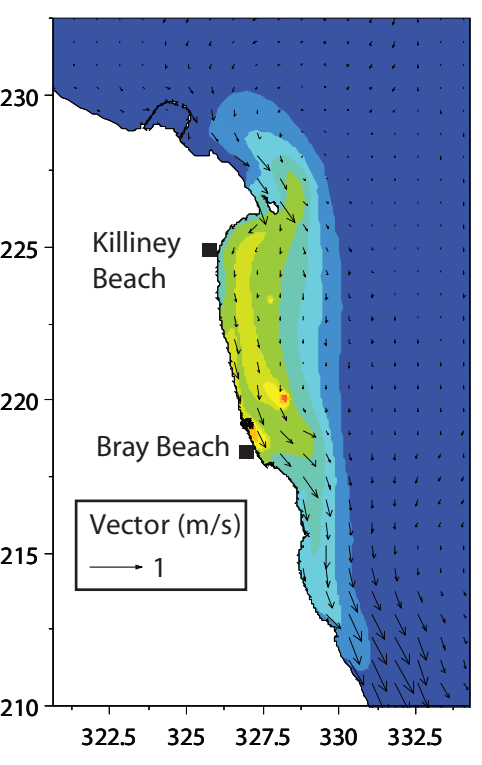

(c) MST-W2 - Sc1
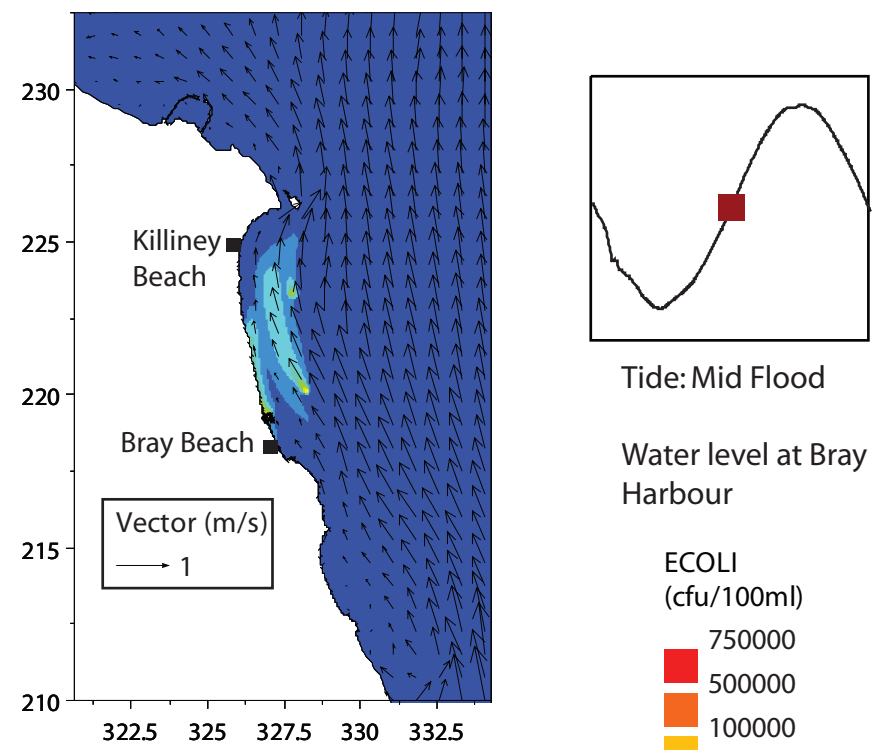

Tide: Mid Flood

Water level at Bray Harbour
ECOLI
(cfu/100ml)
750000
500000
100000

(b) MST-W2 - Sc2 50000

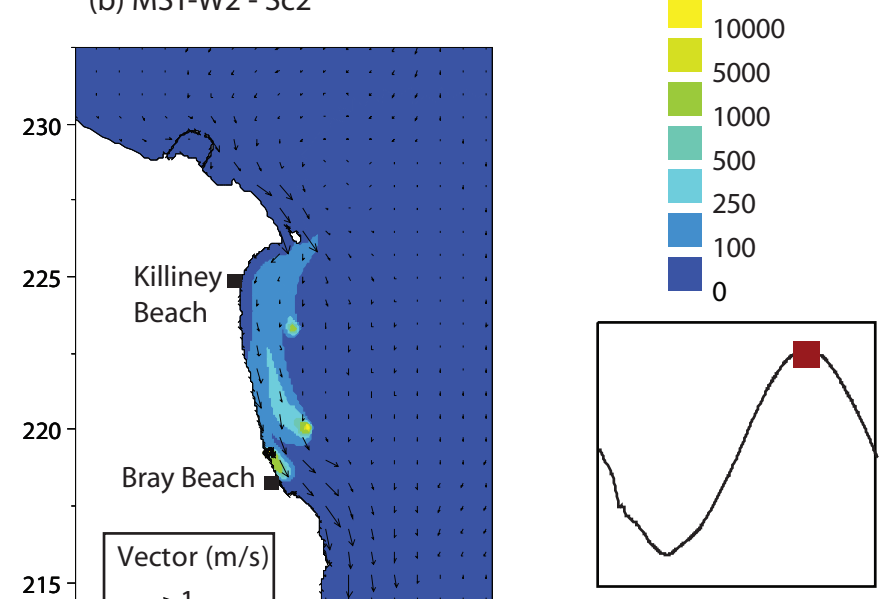

Tide: High Water

Water level at Bray Harbour
(d) MST-W2 - SC2 